NBER WORKING PAPER SERIES

\title{
ECONOMIC AND POLITICAL INEQUALITY IN DEVELOPMENT: THE CASE OF CUNDINAMARCA, COLOMBIA
}

\author{
Daron Acemoglu \\ María Angélica Bautista \\ Pablo Querubín \\ James A. Robinson \\ Working Paper 13208 \\ http://www.nber.org/papers/w13208 \\ NATIONAL BUREAU OF ECONOMIC RESEARCH \\ 1050 Massachusetts Avenue \\ Cambridge, MA 02138 \\ June 2007
}

We would particularly like to thank Malcolm Deas for introducing us to the Catastros de Cundinamarca and for his extraordinary generosity with his time and knowledge of Colombian history. We also thank Peter Evans for his discussions and conference participants and Brown, the Canadian Institute of Advanced Research, the All-UC Economic History Conference at UC Davis, IMF, the Kennedy School, Maryland, MIT, and the World Bank for useful suggestions, particularly Allan Drazen, Daniel Trefler and Michael Walton. We are also grateful to Catalina Bautista, Leopoldo Fergusson, Maria Alejandra Palacio, Diana Rodriguez and Olga Lucia Romero for help in putting the data together on which the research is based. The views expressed herein are those of the author(s) and do not necessarily reflect the views of the National Bureau of Economic Research.

C 2007 by Daron Acemoglu, María Angélica Bautista, Pablo Querubín, and James A. Robinson. All rights reserved. Short sections of text, not to exceed two paragraphs, may be quoted without explicit permission provided that full credit, including $\odot$ notice, is given to the source. 
Economic and Political Inequality in Development: The Case of Cundinamarca, Colombia Daron Acemoglu, María Angélica Bautista, Pablo Querubín, and James A. Robinson

NBER Working Paper No. 13208

June 2007

JEL No. H27,N01,N1,N16,O1,O11,O16,O54

\begin{tabular}{|c|c|}
\hline \multicolumn{2}{|c|}{$\underline{\text { ABSTRACT }}$} \\
\hline \multicolumn{2}{|c|}{$\begin{array}{l}\text { Is inequality harmful for economic growth? Is the underdevelopment of Latin Ame } \\
\text { unequal distribution of wealth? A recently emerging consensus claims not only that ecc } \\
\text { has detrimental effects on economic growth in general, but also that differences in ecc } \\
\text { across the American continent during the 19th century are responsible for the radically } \\
\text { performances of the north and south of the continent. In this paper we investigate this } \\
\text { unique 19th century micro data on land ownership and political office holding in the state } \\
\text { Colombia. Our results shed considerable doubt on this consensus. Even though Cundir } \\
\text { more unequal than the Northern United States at the time, within Cundinamarca m } \\
\text { were more unequal in the 19th century (as measured by the land gini) are more develope } \\
\text { we argue that political rather than economic inequality might be more important } \\
\text { long-run development paths and document that municipalities with greater political inequ } \\
\text { by political concentration, are less developed today. We also show that during th } \\
\text { the politically powerful were able to amass greater wealth, which is consistent with or } \\
\text { through which political inequality might affect economic allocations. Overall our fin } \\
\text { on the conventional wisdom and suggest that research on long-run comparative dev } \\
\text { investigate the implications of political inequality as well as those of economic in }\end{array}$} \\
\hline Daror & Pablo Qu \\
\hline Economics & hent of Economics \\
\hline MIT, E52-380B & 50 Memorial Drive \\
\hline 50 Memorial Drive & Cambridge, MA 02142 \\
\hline $\begin{array}{l}\text { Cambridge, MA 02142-1347 } \\
\text { and NBER }\end{array}$ & querubin@mit.edu \\
\hline daron@mit.edu & $\begin{array}{l}\text { James A. Robinson } \\
\text { Harvard University }\end{array}$ \\
\hline María Angélica Bautista & Department of Government \\
\hline Brown University Department & N309, 1737 Cambridge Street \\
\hline & \\
\hline 36 Prospect Street & and NBER \\
\hline & \\
\hline
\end{tabular}




\section{Introduction}

A large and growing academic literature argues that economic inequality has adverse effects on economic development, for example, because of the effects of imperfect capital markets, through demand externalities, or because of political economy reasons. ${ }^{1}$ A recently-emerging consensus, exemplified by Engerman and Sokoloff (1997), maintains that the divergent economic paths of North and South America are a consequence of their different levels of economic inequality. This consensus asserts that the main difference between the two parts of the American continent was the differences in economic inequality that emerged during the colonial period and persisted to the 19th century, and links the current economic difficulties of South American nations to their greater inequality.

A major empirical challenge for this view, however, is that economic inequality is also correlated with many other potential determinants of long-run development. Most important for the focus of this paper, economic inequality may be associated with political inequality, in the sense that collective choices reflect the wishes and interests of a small subsection of the society. Theoretically, we may expect economic inequality to lead to political inequality (as the economically powerful become politically more influential), but the reverse link is at least as important, as those with political power will be able to amass greater economic wealth. To illustrate this point, note that there is a negative relationship between land inequality and development not only when we compare the United States to South America, but also across the US states. For example, Figure 1 shows a plot of the land gini in each US state in 1860 against total school enrollment in 1870 (see below for data details). There is a clear negative relationship, with the more unequal Southern states having lower enrollments. Figure 2 plots the relationship between the land gini in 1860 against the enrollment rate in 1950 and shows that this relationship persists to the 20th century. ${ }^{2}$ Do these correlations establish that there is an adverse effect of economic

\footnotetext{
${ }^{1}$ On the effect of inequality because of its interactions with imperfect capital markets see, for example, Banerjee and Newman (1993) or Galor and Zeira (1993). For the impact of inequality through the composition of aggregate demand, see, for example, Murphy, Shleifer and Vishny (1989). More important for the application of these theories to Latin America and for the focus of the present paper are the political economy mechanisms linking inequality to economic development (see, among others, Meltzer and Richard, 1981, Alesina and Rodrik, 1994, Persson and Tabellini, 1994, Benabou, 2000). In addition, some authors emphasize the link between inequality and political instability (Alesina and Perotti, 1996) and on incentives to invest in education (Bourguignon and Verdier, 2000, Galor, Moav and Vollrath, 2006). See Benabou (1996) and Aghion, Caroli and García-Peñalosa (1999) for surveys of this literature.

${ }^{2}$ A similar relationship between land inequality and education across US states is documented in Galor, Moav and Vollrath (2006) and Ramcharan (2006).
} 
inequality on schooling? While this is a possibility, one also has to bear in mind that the US states with greater economic inequality are also those with greater political inequality. For example, the Southern states were not only more unequal economically, but exhibited a very high degree of political inequality, with a large fraction of the population disenfranchised and large planters controlling politics directly or indirectly. Therefore, one can imagine that it might be the relationship between political inequality and economic outcomes that underlies the patterns shown in Figures 1 and 2. Political inequality may retard development because elites who control politics may create rents for themselves, impede entry (Acemoglu, 2007a), and have little interest in the provision of public goods, including schooling (Bates, 1981). Political inequality will also tend to be associated with the absence of political competition and accountability, two factors which help to guarantee that political systems generate desirable outcomes. ${ }^{3}$

Is it economic or political inequality that matters for long-run development? And how does inequality in general interact with the institutional structure of a society in shaping its development path? These questions are made interesting in part because even though it is typically asserted that economic and political inequality go hand in hand, particularly in Latin America and across US states, this is not necessarily so everywhere else in the world, or even, as we show, in Colombia. For example, in much of Sub-Saharan Africa since independence measured economic inequality has been quite low, but political inequality has been severe with rule by long-running autocrats or small cliques, most clearly in the Sudan, Angola, the Congo, Malawi, Côte d'Ivoire, Togo and the Cameroon. This combination led to disastrous development outcomes. In contrast to the African cases, development in South Korea and Taiwan seems to have taken place precisely in the context of economic equality, but under dictatorial regimes, with political power concentrated in the hands of a small elite. Finally, there are examples of rapid development with high economic inequality but relative political equality, such as Mauritius in the 1970s and 1980s. It is therefore important to attempt to "unbundle" the separate effects of economic and political inequality on long-run development both to gain a better understanding of the causes of the process of economic development and to evaluate the newly emerging conventional wisdom about the sources of underdevelopment in Latin America.

Despite the importance of the aforementioned questions, they have not been tackled by the existing literature. The early cross-country work finds a negative correlation between economic inequality and growth (for example Alesina and Rodrik, 1994, Persson and Tabellini, 1994, Per-

\footnotetext{
${ }^{3}$ Acemoglu and Robinson (2000a, 2006a) also suggest that in societies with significant political inequalities, those with political power may block the introduction of new technologies or underinvest in public goods because of the fear that this will erode their political power.
} 
otti, 1996), but as noted above, this work does not distinguish between political and economic inequality, which are often highly correlated. Moreover, even the negative correlation between economic inequality and subsequent growth appears to be non-robust (Barro, 2000, Forbes, 2000, Banerjee and Duflo, 2003). ${ }^{4}$ There is also micro evidence on the relationship between economic inequality and development, for example Benjamin, Brandt and Giles (2006). The issue of the effects of political inequality has not been systematically addressed, however, except to the extent that it can be associated with the absence of democracy. While some theoretical papers suggest that democracy ought to be good for development (Acemoglu, and Robinson, 2000b, Lizzeri and Persico, 2005), others argue the relationship is ambiguous (Acemoglu, 2007a) and the empirical literature mostly finds no effects (Barro, 1997), though Bond, Barndt, Gerring and Moreno (2005) and Persson and Tabellini (2006) find a positive effect of the cumulative democratic history of a country on economic growth.

In this paper we investigate the influence of economic and political inequality on long-run development using microdata from the state of Cundinamarca in Colombia. Our focus is the critical period of development in the late 19th century when Latin American economies began to grow and integrate with the world market. Cundinamarca provides a natural setting for such an investigation since it was the center of the largest pre-Columbian civilization in Colombia, the Muiscas. It also contains Bogotá the capital both of colonial and independent Colombia. In many ways, Cundinamarca was at the heart of the Spanish colonial system. Our investigation is made possible by unique data on 19th-century land ownership. In 1879 and 1890 the state of Cundinamarca undertook comprehensive land censuses (catastros) which recorded the identity of each landowner in the state, the name of their farm and the value of their land. We use these data to construct gini coefficients for the distribution of landed wealth. The land gini is both a natural and easy to interpret measure of economic inequality, and it is used commonly in the literature. Moreover, by focusing on land inequality, we can capture the major source of economic inequality in South America emphasized by Engerman and Sokoloff (1997). ${ }^{5}$

To measure political inequality we collected data on the identity of all of the mayors of the municipalities of Cundinamarca for the period 1875 to 1895. Specifically, we construct an index of

\footnotetext{
${ }^{4}$ To deal with the ubiquitous omitted variable biases in such regressions, Easterly (2007) instruments inequality with the extent of land suitable for growing sugarcane and finds a negative effect on growth. Since the presence of sugar plantations may create negative effects through a variety of channels, including political inequality, this evidence does not establish that it is economic inequality that matters or that there is a causal effect from overall economic inequality to growth.

${ }^{5}$ Though some of these data has been discussed by historians, for example Jiménez (1985), and Palacios (1981) provided an analysis of the 1879 data for the entire department, we are the first to study these data more systematically and examine the long-run consequences of land inequality in Cundinamarca.
} 
political concentration, which measures the extent to which political officeholding was monopolized by individuals. Throughout this period, the right to vote in Cundinamarca was restricted by property and literacy requirements. Nevertheless, the distribution of political power varied a lot across different municipalities of Cundinamarca, with some having frequent turnover of mayors, while in others the same family or small group of families kept power for extended periods. ${ }^{6}$

Finally, our data also enable us to investigate another interesting related question, the developmental implications of the overlap between economic and political power. In particular, having both political and economic power concentrated in the hands of a small group of individuals creates both benefits (since the politicians are willing to choose policies that encourage investment as this increases the value of their own assets) as well as costs (since a greater degree of elite control of politics and the economy can lead to the existence of a landed oligarchy, which may be costly for development). ${ }^{7}$ We investigate these questions by constructing an index of overlap, which measures the extent to which large landowners and politicians were the same people. ${ }^{8}$

The main results of the paper are as follows. First, by way of comparison, using micro data from the 1860 US census, we show that while the distribution of landed wealth in Cundinamarca was considerably more unequal than Northern US states, it was less unequal than in the US South. ${ }^{9}$ More important and somewhat surprising, we find a negative association between land inequality (land gini) and political concentration across municipalities in Cundinamarca. Though this is inconsistent with the stylized picture that, at least in Latin America, political and economic inequality often covary, it is actually consistent with the historical literature on Colombia which

\footnotetext{
${ }^{6}$ We calculated political concentration both at the level of individuals and aggregating last names to the level of families. However, the results with families were very similar and in the paper we report results only with individuals.

${ }^{7}$ Classic works that emphasize the cost of landed oligarchy in Latin America include Stein and Stein (1970), Gilbert (1977), Stone (1990), and Paige (1997). See Schwartz (1996) for a review of the facts and issues. Acemoglu (2007a) and Acemoglu and Robinson (2006b) present models in which such concentration of power can lead to adverse effects. On the other hand, many simple political economy models suggest that congruence of interests between the politically and economically powerful may be good for economic development (see, for example, Acemoglu, 2007b).

${ }^{8}$ There is an interesting literature that indirectly speaks to this issue. This literature finds that connections between politicians and firms tend to raise the asset prices of firms (Fisman, 2001, Johnson and Mitton, 2003, Faccio, 2006), get them preferential access to loans from government banks (Khwaja and Mian, 2005) or policy favors (Bertrand, Kramarz, Schoar and Thesmar, 2006). Bertrand et al. (2006) also find that politically connected firms alter their decisions in response to political incentives. However, this literature has not looked at the implications of these linkages for development outcomes.

${ }^{9}$ This in itself is important. We know little about the basic historical facts on comparative wealth inequality in Latin America and what we do know is not always consistent with the view espoused by Engerman and Sokolof (1997) that Latin America always had greater economic inequality than the United States (see Jones, 1980, Johnson, 1994). Most notably, Coatsworth (1998) argues that greater inequality in Latin America is a relatively recent phenomenon associated with the economic developments of the late 19th century, leading to some group of politically-powerful individuals monopolizing large productive stretches of land. Our result that land inequality in the US South was greater than in Cundinamarca provides support to this viewpoint.
} 
stresses that politics was a career open to people of many backgrounds (see Safford, 1972, 1974, Deas 1993, and Uribe-Uran, 2000).

Our second set of results are rather surprising. When we look at current outcomes, we find that land gini (economic inequality) is positively associated with good outcomes. For example, areas that were more unequal in the late 19th century have higher levels of secondary and primary school enrollment, lower poverty and higher urbanization. Figure 3 shows the relationship between the land gini at the end of the 19th century and contemporary secondary school enrollment in Cundinamarca. In contrast to Figures 1 and 2 for the United States, there is now a positive relationship. A natural concern is that this positive relationship may reflect the effect of some omitted factors, such as higher land quality in places with higher inequality. We attempt to deal with potential sources of omitted variable bias by controlling for a rich set of geographic characteristics and current land inequality. Overall, our results suggest that the relationship shown in Figure 3 is relatively robust. We also find similar results when we look at outcomes at intermediate dates, such as data from the 1937 census. The estimated effects are also large economically. For instance, the historical land gini on its own accounts for about $30 \%$ of the variation in the contemporary outcome variables.

Even though this correlation does not establish a causal effect, it is difficult to rationalize with theories that argue for a direct causal link from economic inequality to long-run economic development, such as that in Engerman and Sokoloff (1997). This is particularly challenging to the view that greater land inequality will have negative effects on economic development by depressing education, for example as articulated by Galor and Zeira (1993), Benabou (2000), Engerman and Sokoloff (1997), Galor, Moav and Vollrath (2006) and Ramcharan (2006). Our evidence shows that land inequality is uncorrelated with literacy in 1937 and has a positive effect on primary and secondary school enrollment in 1993.

When we turn to political variables, however, we find a fairly robust negative relationship between political concentration (our measure of political inequality) and good economic outcomes. Figure 4, for example, shows a significant negative relationship between our index of political concentration at the end of the 19th century and secondary school enrollment today. In contrast, we find no robust effect of the overlap measure discussed above on either long-term or mediumterm outcomes.

Though difficult to reconcile with the conventional wisdom, our findings are consistent with other strands of research, including both the historical literature on Colombia and Latin America and work by Bates (1981) on the political economy of Africa. Bates (1981) documented that eco- 
nomic policy in post independence Kenya was more conducive to better economic outcomes than in Ghana because of the balance of power between politicians and economic elites in the former country. In Ghana, smallholders growing cocoa could not solve the collective action problem and were unable to restrain politicians from engaging in costly clientelism and choosing highly distortionary economic policies. In Kenya, mostly as a legacy of white settlement in the highlands, farm sizes were larger and an agricultural elite was able to organize and check the power of the politicians in Nairobi. In consequence, better policies and economic outcomes resulted. Therefore, Bates's comparison of Ghana versus Kenya provides an example in which greater (land) inequality led to better economic outcomes. ${ }^{10}$

In this light, a possible interpretation for our results is that powerful and rich landowners may be creating checks against the most rapacious tendencies of politicians. Consequently, in the municipalities with major landowners, distortionary policies that could be pursued by politicians were limited, and this led to better economic outcomes. This interpretation is also consistent with the negative association between political inequality and economic outcomes (as well as the negative relationship between economic and political inequality we find in Cundinamarca). Though plausible, this explanation is in stark contrast to both the conventional wisdom about the source of underdevelopment in Latin America and to the insights of many economic models emphasizing the negative effects of inequality by restricting access to credit or through political economy mechanisms. As a check on the plausibility of our interpretation, we use the microdata from the Cundinamarca land censuses to construct a separate overall land gini. While the standard measure of the land gini captures inequality among landowners, the overall land gini measures inequality in the entire population, assigning zero land holdings to families without any land. According to Bates's hypothesis, it should be land inequality among landowners-i.e., the standard land gini - that should have a positive effect, while overall land gini should have no impact on economic outcomes. According to the Engerman-Sokoloff type hypotheses and to economic models emphasizing the adverse effects of inequality, both of these measures should have a negative effect on economic development. We find that when both measures are included together, it is inequality among landowners - the standard land gini - that has a positive effect on subsequent

\footnotetext{
${ }^{10}$ Our findings and this interpretation are also consistent with Coatsworth $(1998,2005)$ and Nugent and Robinson (2002), who have emphasized that economic inequality in Latin America is better thought of as an outcome of the unequal distribution of political influence. In turn these more general arguments echo a large literature by historians, for instance Solberg (1969) or McCreery (1994).

Our results are also consistent with Banerjee and Somanathan's (2006) finding that higher land inequality is associated with greater public good provision in India. They suggest that this may be because higher land inequality allows landowners to solve their collective action problems.
} 
economic outcomes, while the overall land gini has a small negative and insignificant impact.

One question raised by our interpretation is the source of the difference between the results we find in Cundinamarca and the patterns across US states in the 19th century, where land inequality appears to be strongly negatively correlated with economic outcomes. We believe that the answer to this question may lie in the differences in the level of political development between the United States and Colombia. Like 20th century Africa, Colombia in both the 19th and 20th centuries can be characterized, in the terminology of Acemoglu, Robinson and Verdier (2004), as "weakly institutionalized" in the sense that political institutions placed few constraints on what actions politicians could take. Bates' insight was that in such circumstances land inequality may be associated with better outcomes because, at least when landed elites are distinct from politicians, such elites can check the power of politicians. In the central areas of Cundinamarca, where landed elites were more consolidated and land inequality higher, they were able to constrain politicians. In consequence political concentration was lower. In more peripheral areas of the department, it was easier for politicians to consolidate their hold on power since there was no strong economic elite to counterbalance their power. When unchecked, politicians were less accountable and, as we show, were able to accumulate large amounts of land and wealth. The resulting political economy also appears to have involved a severe lack of public good provision. In contrast, the relationship between inequality and economic outcomes appears to be different in strongly institutionalized environments such as the United States. Here, political institutions place certain constrains on politicians so that having a strong landed elite is not necessary as a check against politicians and does not necessarily create a tendency for better outcomes. Rather, and possibly consistent with the US evidence, in such environments greater inequality may have negative economic or political consequences (for example, in the extreme via "political capture," as in Acemoglu and Robinson, 2006b, or Acemoglu, Ticchi and Vindigni, 2006). This description is broadly consistent with the situation in the US South. Landed elites in the Southern US, both in the pre and post-bellum periods, tended to have more say in politics and were able to use their power strategically to generate rents for themselves, by creating a low-wage, low-skill labor market and by underinvesting in education so as to make the plantation labor force easier to control and less mobile (Wright, 1986, Margo, 1990).

Therefore, the overall pattern that emerges from this interpretation is one that can be summarized schematically as follows: ${ }^{11}$

\footnotetext{
${ }^{11}$ Our discussion and the schematic summary above represent the US South as "strongly institutionalized". An alternative is to view the US South, just as the 19th-century Colombia, as weakly institutionalized. In this case, the outcomes in the US South are the intermediate outcomes generated by highly unequal weakly-institutionalized poli-
} 


\begin{tabular}{|c|c|c|c|c|}
\hline & $\begin{array}{l}\text { high economic } \\
\text { inequality }\end{array}$ & Examples & $\begin{array}{l}\text { low economic } \\
\text { inequality }\end{array}$ & Examples \\
\hline $\begin{array}{l}\text { weakly } \\
\text { institutionalized } \\
\text { polities }\end{array}$ & $\begin{array}{l}\text { better property } \\
\text { rights }\end{array}$ & $\begin{array}{l}\text { Kenya } \\
\text { Central } \\
\text { Cundinamarca }\end{array}$ & $\begin{array}{l}\text { worse property } \\
\text { rights }\end{array}$ & $\begin{array}{l}\text { Ghana } \\
\text { Peripheral } \\
\text { Cundinamarca }\end{array}$ \\
\hline $\begin{array}{l}\text { strongly } \\
\text { institutionalized } \\
\text { polities }\end{array}$ & $\begin{array}{l}\text { captured } \\
\text { politics }\end{array}$ & Southern US & $\begin{array}{l}\text { competitive } \\
\text { politics }\end{array}$ & Northern US \\
\hline
\end{tabular}

Our final set of results also provide support for the interpretation presented above. We exploit the micro data on land holdings and the identity of politicians to investigate the mechanism via which political inequality might be affecting economic outcomes. In particular, we use linear and quantile regressions to document that those with political power are able to increase the value of their land holdings much more rapidly than others. In particular, an individual who remains a politician for four years triples the value of his landholdings relative to other landowners. This is a very large effect, suggesting that politicians are able to use their position in order to increase their wealth substantially. These results illustrate a direct mechanism through which political power played an important role in the allocation of economic resources in 19th-century Cundinamarca. ${ }^{12}$ Finally, consistent with these results, we also find that those with political power seem to be significantly more likely to acquire additional land than the likelihood of those with land to become politicians.

Overall, even though what we present in this paper are historical correlations (not necessarily estimates of causal effects or structural parameters), they are both challenging to the conventional wisdom and paint a picture very different from those obtained from cross-country studies and from the within-US variation shown in Figures 1 and 2. At least for Cundinamarca (and as we will show below, for Colombia as a whole), there is no evidence that greater land inequality is associated with bad economic outcomes. On the contrary, greater land inequality more than 120 years ago has a positive predictive power for economic outcomes today, even after controlling for current land inequality and a variety of geographic controls. In contrast, greater monopolization of political power in the hands of particular families or individuals during the 19th century seems to be robustly associated with worse outcomes today.

ties, which are inferior to those arising in strongly-institutionalized polities such as the US North. This alternative perspective is consistent with all the results we present in this paper and with our general interpretation, though we believe that the power of the Federal State in the United States in the 19th century put certain real restrictions on politics in the South and justifies our schematic representation of the South as strongly institutionalized.

${ }^{12} \mathrm{~A}$ number of caveats are once again important to note. First, unobserved heterogeneity in the talents of different individuals might be responsible for some of these results. Second, our regressions are not informative about whether this process of political power leading to economic wealth is efficient or inefficient. 
The paper proceeds as follows: in Section 2 we describe the historical and institutional setting of Cundinamarca and some of the relevant literature. Section 3 describes the historical and contemporary data we use in this paper and introduces the measures of land gini, political concentration and overlap. Section 4 compares land inequality in Cundinamarca to inequality in US states around the same time. In Section 5 we examine the correlations between these variables and long-run outcomes in 1993 and 1937. Sections 6 and 7 examine the dynamics of wealth accumulation and political office holding. Section 8 concludes.

\section{The Setting}

In this section, we provide some relevant background information about the history and institutions of Cundinamarca and Colombia and discuss in more detail the relationship between our work and the relevant historical and social scientific literatures. The modern department of Cundinamarca ${ }^{13}$ was the heart of the Muisca civilization at the time of the conquest of Colombia and the capital of Colombia, Bogotá, is located in the middle of the department. Since the greatest density of indigenous peoples were in Cundinamarca and the neighboring department of Boyacá, Spanish colonial institutions originated here and the first grants of encomienda, the institution which allocated the labor and tribute of indigenous peoples to conquistadors, were given by the conquistador Gonzalo Jiménez de Quesada in this region beginning in $1538 .{ }^{14}$ Subsequently large haciendas emerged in Cundinamarca and throughout the colonial period the department remained at the heart of state and society in the Spanish province of New Grenada. ${ }^{15}$ This situation persisted after independence with Bogotá remaining the capital and in the period we study Cundinamarca was clearly at the heart of national politics and the home of a great deal of the most important sections of the political elite. ${ }^{16}$

From at least the 1850 presidential election onwards political conflict in Colombia coalesced around two parties, the Conservatives and Liberals. In 1850 the Liberals won the presidency for the first time and José Hilario López became president. From then until 1885 the Liberals controlled the central state except for a brief period after 1856 when they lost a presidential election to the Conservatives held under universal male suffrage (Bushnell, 1971). The Liberals

\footnotetext{
${ }^{13}$ The name for the department stems from an Indian phrase Kundur marqa which means the "Condor's nest."

${ }^{14}$ The best overview of the colonial period are Colmenares (1973), Melo (1996) and the early chapters of Safford and Palacios (2001).

${ }^{15}$ Some narrative information on the emergence of haciendas in central Cundinamarca is in Pardo Umaña (1946) and Villamarin (1975).

${ }^{16}$ Key Conservative Presidents such as Miguel Antonio Caro (President between 1894-1898) and José Manuel Marroquín (President 1900-1904), both of whom appear in the 1890 catastro, lived their entire life on the Sabana de Bogotá, the intermontane plane on which Bogotá sits.
} 
shortly afterwards reclaimed control through a brief civil war and wrote a new liberal constitution at Rionegro in 1863. ${ }^{17}$ The Rionegro constitution was highly federal and the right to determine who could vote was delegated to the states.

In 1885 there was another civil war between the parties and power switched to the Conservatives until 1930. This period, known as the Regeneración (Regeneration) led to the re-writing of the constitution and an undoing of many of the policies promoted by the Liberals. In particular, federalism was abolished and power was centralized to the national state. There were also important changes in economic policies, for example a significant increase in tariffs and a general movement away from free trade. ${ }^{18}$ The Liberal election victory of 1930 led to the introduction of universal male suffrage in 1936 and the introduction of more progressive social and labor market policies but led to increasing political polarization between the parties which culminated in the victory of Conservative Mariano Ospina in 1946 followed by a partisan civil war (the so-called $L a$ Violencia) which led to a military coup in 1953. The parties negotiated a return to democracy in 1958.

There are many interpretations of long-run development in Colombia from various perspectives. The 19th century Liberal politicians and intellectuals, such as Manuel Murillo Toro, Salvador Camacho Roldán, José Maria Samper and Miguel Samper, wrote extensively on economic matters and promoted a version of classic 19th-century liberalism as the way to modernize and develop the country. Vestiges of the colonial system were one of the main things they criticized. During the Liberal period between 1850 and 1885 tariffs were cut, monopolies abolished, the remnants of colonial institutions such as slavery finally destroyed, and Church lands were expropriated. However, the Liberal period also generated significant economic and political instability, and McGreevey (1970) argues that there was a notable increase in inequality during this era. Despite transitory booms it was only with the sustained expansion of the coffee economy from the 1880s onwards that economic growth began in Colombia. Growth has been sustained but slow ever since, and after 1900 Colombia has remained at about $18 \%$ of US GDP per-capita (Robinson and Urrutia, 2007). The development of the coffee industry was linked most famously to a frontier expansion into the current states of Caldas, Risaralda and Quindío which is typically characterized as rather egalitarian by Latin American standards (the classic work is by Parsons, 1949).

For our focus, the institutions governing the selection of mayors and their powers are essential.

\footnotetext{
${ }^{17}$ The best overviews of politics in this period are Delpar (1981), Park (1985).

${ }^{18}$ For overviews of the politics of this period see McGreevey (1970), Bergquist (1978), Posada-Carbó (1997) or Mazzuca and Robinson (2006).
} 
During the Liberal period mayors were appointed by the departmental governors who were themselves elected. After 1885 and the centralization of power, governors still appointed mayors but were themselves appointed by the president of the Republic. Municipal councilors were elected throughout the entire period. The centralized appointment of mayors was only abandoned in 1986. Before 1885 the governor of Cundinamarca was a Liberal ${ }^{19}$ except for a brief period in 1867 when a Conservative, Ignacio Gutiérrez was elected, only to be replaced with a Liberal by the federal government in 1868 (Delpar, 1981, p. 96). After 1880 the governor was a more moderate Liberal from the camp of President Rafael Núñez (called Independents) and by the time of Núñez's second presidency after 1884 Independents were cooperating with Conservatives in the department (Park, 1985, p. 250). Under the Political and Municipal Code of 1858 (Estado de Cundinamarca, 1859) mayors were appointed each year along with a substitute and the term of the mayor was six months after which he was replaced by the substitute for six months. Article 130 of the code says "At the end of each term, the substitute becomes the mayor and executes the functions in the next period; only in extraordinary cases there will be a new appointment of the mayor, since in ordinary cases the only appointment that can take place is the one for the substitute each semester." In practice, however, repeated terms for the same mayor were common. For example, in Suesca, Rafael Olaya was mayor continually from 1871 to 1883 (Olaya was also the fifth largest landowner in the municipality with land worth 24,000 pesos in 1879 when then mean value of land in the municipality was 1,429 pesos). After 1885 , the law was changed so that the term of a mayor became one year and mayors could be officially reappointed (Estado de Cundinamarca, 1889, Article 227).

In terms of the power and responsibilities of the mayor, Article 127 of the 1858 code says that "The mayor is the highest figure of the public administration in the District, and as the representative of the Executive Power he is in charge of the execution of the laws in the District." Mayors were in charge of raising property taxes ('rents') to fund schools and Article 298 of the 1858 code states that there "Is an obligation for every city, village or parish to maintain a public primary school for boys and another one for girls." Taxes were also supposed to pay for the police and public works such as the maintenance of roads and bridges. Mayors therefore had a large number of tasks with respect to the enforcement of laws and the provision of public goods and Cruz Santos (1965, Volume I, p. 519) estimates that in 1869-1870 about 23\% of total government expenditures were decided at the municipal level.

\footnotetext{
${ }^{19}$ Even though the period before 1885 was dominated at the national level by Liberals, Conservatives controlled the states of Antioquia and Tolima.
} 
One of the most important parts of the mayors' responsibilities from the point of view of this paper was his role in adjudicating land disputes. During the 19th century large areas of government owned land, or baldios, were distributed to individuals in Colombia and there were constant disputes over the title to lands. Although the right to "regulate the distribution or destiny of uncultivated lands" was delegated to the municipal councils, the secondary literature on this makes it very clear that mayors played a pivotal role in determining the outcome of these conflicts, probably because they were in charge of the police. Palacios' (1980) seminal work on the evolution of the coffee economy in Colombia has an extensive discussion of the allocation of land and property rights noting that "local control of power was the sine qua non in this process of distribution" (p. 186). Although national laws gave "squatters" the chance to file for title in government lands if no other previous title existed, the reality was that many were expropriated by those who controlled the instruments of local political power. LeGrand (1986, p. 73) notes "By their compliance with or disregard of legal prescriptions, municipal authorities shaped the expression and resolution of the public land conflicts. Given their strategic position in the bureaucratic hierarchy, they also played a significant role in interpreting the issues involved in any given dispute to authorities at higher levels." Mayors and local police were the people who evicted squatters and supported or denied claims to land ownership. Both Palacios (1980, pp. 185-195) and LeGrand illustrate this with many stories. For instance, LeGrand describes the typical way in which squatters would be forced to recognize the title of the politically powerful: "Once entrepreneurs had established property rights over the land, whether through grants or by illegal means, they then took action to deprive the settlers living there of their independence. Accompanied by the local mayor or a police patrol, they informed the settlers who had opened the land that they had mistakenly occupied private property" (p. 58).

Who were these mayors? Christie $(1979$, p. 50) in his study of local political bossesgamonales (also known as caciques) — argues "Only sometimes were they the largest landowners," and LeGrand (1986, p. 73) asserts "Large landowners, for the most part, declined to occupy local political posts." One interesting source on these matters is Rufino Gutiérrez who in his capacity as Prefect visited many municipalities of Cundinamarca in 1886 and 1887 and subsequently wrote a memoir (Gutiérrez, 1920). ${ }^{20}$ Gutiérrez (pp. 90-91) points out that few mayors were important landowners, but instead tended to be from small landowners. He argues that the major landowners

\footnotetext{
${ }^{20}$ Article 115 of the 1858 Municipal Code states that "The Prefect, as political representative of the Executive Power, is in charge of the Political administration of the Department and the Corregidores and Alcaldes are subject to him," Article 116 continues that the Prefect will "visit all the Districts of the Department once in a year and find out if the laws have been implemented and enforce them for a better execution."
} 
used their influence to get mayors appointed who would favor their interests (see also Deas, 1971, on local politics). These conclusions are consistent with the general historiography on Colombia which, following Safford $(1972,1974)$, has played down the political role of large landowners. Though Colombia did have land-owning caudillos like José Maria Obando and Tomás Mosquera, this literature claims that, by and large, politics was a career in 19th-century Colombia and attracted people from all backgrounds (see also Uribe-Uran, 2000). Our empirical findings are partially consistent with this view. We find that there were many non-land-owning mayors (often using their powers to enrich themselves), though there was also some overlap between landowners and politicians. Indeed in a number of municipalities, there were close links between the largest landowners and local politics. In addition to the case of Suesca discussed above, in Fomeque the largest landowner, Manuel Pardo Rojas (land valued at 20,020 pesos in 1879 when the mean land value of landholdings in the municipality was 989 pesos) was mayor six times. In Une, Simon Rojas (land holding of 3,500 pesos when the mean was 883 pesos) was mayor ten times between 1873 and 1883. There are many other examples of mayors belonging to the top quintile of the land distribution.

Moreover, as Christie $(1979,1986)$ himself showed, elite families were heavily involved in local politics. Christie, in his re-examination of the nature of frontier expansion in 19th century Colombia, compiled a list of the mayors and members of the local councils of all the municipalities of Viejo Caldas up until 1905. Using documents on the history of Manizales and other municipalities, Christie was able to determine the 27 most prestigious families who were also owners of great land concessions in the region. Matching the official posts with the last names of these families, he estimated that during the period between 1827 and 1905 more than 2,500 out of the 3,500 positions available were occupied by members of these families. When doing the same exercise but for the year 1920 this time, Christie found that $75 \%$ of the mayors came from the same families.

What do we know about the process by which mayors were appointed? Though we do not have direct evidence on this, the most likely process that drove the appointments is that governors had to respect local power structures and local gamonales and caciques. Neither the central state nor the department of Cundinamarca had military forces that were sufficient to intervene effectively in local politics and in practice it was probably impossible to overturn local power structures, even had there been an incentive. Evidence supporting this interpretation comes from the dramatic shift in power with the Regeneración in 1885 in which the Conservatives replaced the Liberals at the national level (see Mazzuca and Robinson, 2006). Even though at the national level the Conservatives drove the Liberals out of the legislature to such an extent that in the 1890s there 
was only one Liberal, Rafael Uribe Uribe, in the legislature, in most municipalities the same mayors were appointed before and after the Regeneración. Additional evidence consistent with this pattern comes from the Memorias of Gutiérrez. Gutiérrez records that he was called urgently to visit Choachi and found that the public administration was in a terrible shape. He notes that "the person that by that time was the Mayor, Mr. Patrocinio Pardo, did not satisfy the position, for several justified reasons, we demanded his resignation and appointed his substitute Mr. Pedro Angel Garcia" (p. 51). Though Gutiérrez may have removed Patrocinio Pardo, he was back as mayor in 1890, 1891 and 1893, and had previously been mayor in 1878 and 1881 . Pedro Angel García (who was in the top quintile of the land distribution with land of 2,180 pesos when the municipal average was 874 pesos) served as mayor nine times between 1871 and 1891 and several other members of the Pardo and García families did as well. The fact that Patrocinio Pardo could be removed for incompetence but was quickly re-appointed is consistent with the interpretation that the governor, who made the appointments, had to recognize the power of local elites. The situation appears to have been similar in Suesca. Rafael Olaya was removed from the office of mayor in 1873 for manipulating adhesiones - endorsements or declarations of support for different political candidates (Delpar, 1981, p. 102). But our data show that he was immediately re-appointed. Another interesting example comes from Deas' (1977) study of the Hacienda Santa Bárbara in Sasaima. Though he points out that Sasaima was and is a Conservative municipality (p. 286), the first person appointed mayor after the Regeneración was Felipe Castellanos with Esteban García as his alternate. Yet both of these people had been appointed in the Liberal period, Castellanos as mayor in 1879 and 1883 and García in 1880. The probable interpretation of this is that even Liberals had to appoint Conservative mayors in Sasaima.

Finally, the degree of political concentration in Cundinamarca, which we will exploit and document further below, is illustrated by a few prominent examples. For instance, in Viani, out of 44 mayors who held office, half of them corresponded to only 4 individuals and 25 out of the 44 came from either the Bonilla or Hernandez family. In Arbelaez, the Rodriguez family was in power in every single year for which we have data on. With the exception of 1888, Ramon Rodriguez was the mayor in every year between 1887 and 1895. In Quipile, only 3 individuals account for 20 of the 44 mayor appointments that were recorded. Francisco Escobar was the mayor during 1880-1884 and Genaro Mendieta from 1888-1895. In La Calera, a municipality founded by Don Pedro de Tovar in 1765, half of the mayor appointments came from the Tovar family which was in power every year during the 1875-1895 period (except in 1889). In Guasca, almost $70 \%$ of the 51 mayor appointments came from only 3 families and the Acosta and Rodriguez controlled 
power during most of the period. Similarly, most of Cucunubá's mayors came from the Gómez family, which was in power during 1875-1881 and 1887-1895. Today, much of Cucunubá is owned by Pedro Gómez. These are only a few examples that illustrate the way in which power was concentrated in the hands of a few families and individuals in many municipalities.

\section{The Data}

\subsection{Cadastral Data and the Land Gini}

Our basic source of data on economic inequality in 19th century Cundinamarca are the cadastral (land census) data collected by the state of Cundinamarca in 1879 and $1890 .^{21}$ The cadastral information was collected by State officials for tax purposes and provides information on the location, owners and value of every plot with value above $\$ 25$ Colombian pesos in 1879 and above $\$ 100$ in 1890 . The censoring values for each land census are low, so that we have information for most plots. In 1879, there are 15,478 landowners in Cundinamarca and this number increases to 18,598 in 1890 . We have no real information about the reliability of this data though Camacho Roldán (1892) praises the 1868 data as being accurate. Gutiérrez (1920) noted in his visit to Usme in 1886 that the value of lands for that municipality in the catastro was low relative to his own expectations, but he does not systematically record views on this for all the places he visited.

We will construct two measures of land inequality. The first is the standard measure of the land gini coefficient, which measures land inequality among landowners. For each municipality at each date, we construct the gini coefficient using the standard formula

$$
g_{m t}=\frac{1}{n_{t}^{2} \bar{y}_{t}} \sum_{i=1}^{n_{t}} \sum_{j=1}^{n_{t}}\left|y_{i, t}-y_{j, t}\right|
$$

where $i=1, \ldots, n_{t}$ denotes the total number of land owners at time $t, y_{i, t}$ is the value of land owned by individual $i$ at time $t$, and and $\bar{y}_{t}=\frac{1}{n_{t}} \sum_{i=1}^{n_{t}} y_{i, t}$ is the average value of land at time $t$. Throughout most of our analysis, we average the gini coefficients across the two dates for each municipality to arrive to our main measure of (average) land gini. The average gini over this entire period was 0.65 (see Table 1 below). If we look at the two land censuses separately, we find that the land gini was 0.64 in 1879 and increased slightly to 0.66 in $1890 .^{22}$

\footnotetext{
${ }^{21}$ Cundinamarca also undertook such catastros in 1868 and in 1915 . Unfortunately we have been unable to locate these data, possibly because the State archive of Cundinamarca was burned down in April 1948 in the rioting which followed the assassination of the Liberal politician Jorge Eliécer Gaitan, though see Camacho Roldán (1892) for a discussion of the 1868 data. The departments of Tolima and Santander also conducted several catastros in the 19th century but we have also been unable to find these data.

${ }^{22}$ There were however, striking cases of land inequality such as those of Fontibón, formerly the site of the
} 
Despite its widespread use, the land gini suffers from an obvious problem. An area in which all land is held by two very large landowners will have a low value of the land gini, because land is equally distributed among landowners. But if we looked at the population as a whole, there would be tremendous amount of land inequality. To alleviate this problem, we construct an alternative measure, overall land gini, which again computes equation (1), but uses the total number of families and assigns zero land holdings to the families who do not appear in the catastro. ${ }^{23}$ We start our analysis with the land gini and then show how controlling for both the land gini (among landowners) and overall land gini affects the results. ${ }^{24}$

In Figure 5, we superimpose the distribution of the land gini on a map of Cundinamarca. This figure is useful both to show the geographic structure of Cundinamarca and the distribution of municipalities, and also depicts the variation in land inequality. Darker colors in the figure correspond to higher values of the land gini (as indicated in the legend to the figure). The picture reveals that land inequality tends to be higher in the series of intermontane basins to the west and north of Bogotá, but it is also high in the far western municipalities which are down in the valley of the Magdalena river.

\subsection{Political Concentration}

To measure political inequality, we collected data on politician (mayor) names from the Registro del Estado and Gaceta de Cundinamarca, official newspapers which published the names of principal and substitute mayors appointed in each municipality. We were able to find a total of 4763 mayor appointments between 1875 and $1895 .{ }^{25}$ Each appointment however, does not correspond necessarily to a different individual, for the same individuals were sometimes re-appointed in many years. Hence, the 4763 different appointments we collected correspond to 2300 different individuals during this period. A striking fact is the large number of mayors. While in principle, two mayors (principal and substitute) should be appointed per year in each municipality, an average of 2.9 appointments per municipality was observed. This is because there are resignations

encomienda of Jiménez de Quesada, which had a gini coefficient of 0.857 in 1879 and Ricaurte with a gini coefficient of 0.891 in 1890 .

${ }^{23}$ Since the 19th century censuses do not provide information on the number of families or households, but only on the number of individuals, we used the estimate of 10 members per family provided by Gomez (1969) to convert the number of individuals in a municipality into the number of families. We then calculated the number of landless families by subtracting the total number of landowners from the total number of families.

${ }^{24}$ We are only able to compute the overall land gini for Cundinamarca at the end of the 19th century. We do not have micro data for Cundinamarca or the rest of Colombia today, thus the contemporary land gini numbers we use below are for inequality among landowners.

${ }^{25}$ Information was not reported for every single municipality in every year, but there does not appear to be any systematic bias in this. 
and replacements in some years.

We used these data to construct a measure of the concentration of political power. Our measure of political concentration for municipality $m$ at time $t$ is computed as:

$$
p_{m t}=-\frac{\text { Number of Different Individuals in } \text { Power }_{m t}}{\text { Number of mayor appointments } m t} .
$$

The negative sign in front is introduced so that higher values of the index correspond to higher political concentration (thus making the interpretation of the coefficients easier). Consequently, our political concentration index takes a value of -1 when there is very low political concentration, and values close to 0 for high levels of concentration. We computed this index for the whole period 1875-1895. Table 1 shows that the mean of this variable is -0.56 .

Figure 6 is similar to Figure 5 and maps political concentration across the municipalities of Cundinamarca. Now darker colors correspond to higher levels of political concentration. This figure shows that places with higher levels of political concentration are spread out all over the state. They range from municipalities like Beltran in the Magdalena river valley in the west, to Ubala which is on the eastern slopes of the cordillera. Also highly concentrated are the southern coffee growing municipality of Arbelaez, founded in the mid 19th century, and the northern municipality of Sutatausa, an area of dense Muisca settlement and one of the first municipalities to be founded in Cundinamarca.

\subsection{Measuring the Overlap of Wealth and Political Power}

In addition to our basic measures of economic and political inequality, we constructed a measure of the overlap between political officeholding and landed wealth. To do this we classified the individuals in our sample according to whether they were politicians, rich, or both. We define an individual as being both rich and a politician if we can find an exact match of the first and last name in the catastro and in the list of mayors within each municipality. Naturally, this procedure may lead to an overstatement of overlap if we match two different persons with the same first and last name, though this appears to be unlikely within a municipality. On the other hand, there are various reasons for understating overlap, since rich landowners may be politicians in neighboring municipalities or they may have substantial political influence without becoming mayor's themselves.

To construct our measure of overlap, let us introduce some notation. Let $N_{m t}$ be the set of adult males living in municipality $m$ at time $t, L_{m t}$ be the set of adult males without any substantial landholdings or political power, $R_{m t}$ be the rich, i.e. those with substantial landholdings 
and finally let $P_{m t}$ be those with political power (mayors). It is clear that:

$$
N_{m t}=L_{m t} \cup R_{m t} \cup P_{m t}
$$

Let $\# R_{m t}$ be the number of individuals in the set $R_{m t}$, and define $\# N_{m t}$, \# $P_{m t}$, \# $\left(R_{m t} \cup P_{m t}\right)$ and $\# L_{m t}$ similarly. Since we can directly compute $\# P_{m t}$ and $\# R_{m t}$, and observe $\# N_{m t}$, the number of individuals who are neither rich nor politicians can be computed as

$$
\# L_{m t}=\# N_{m t}-\#\left(R_{m t} \cup P_{m t}\right)
$$

For the purposes of our analysis, we define individuals whose land plots are in the top $25 \%$ most valuable plots as "rich landowners". In these calculations, we compute the thresholds for the entire region (and not for each municipality separately) so as to exploit the variation in the presence of big landowners driven by inequality across regions which we want to take into account. ${ }^{26}$ In calculating the number of rich landowners in each municipality, we use the catastros for 1879 and 1890. For politicians, we use neighboring dates to these, so that for 1879, any individual who is a mayor between 1877 and 1882 is considered a politician, and for 1890, we look at the window from 1888 to 1892.

Our measure of overlap in municipality $m$ at time $t$ is computed as

$$
o_{m t}=\frac{\#\left(R_{m t} \cap P_{m t}\right)}{\#\left(R_{m t} \cup P_{m t}\right)} .
$$

Our main measure of overlap is the average of this index for the two dates 1879 and 1890. Table 1 shows that the mean of this variable is 0.07 , so that $7 \%$ of rich landowners and politicians were both rich and in power.

\subsection{Data on Outcomes}

We have two sets of outcome variables. The contemporary data are from the 1993 population census and the Colombian statistical agency DANE (Departamento Administrativo Nacional de Estadística).

We constructed two basic education variables from the 1993 census; primary school enrollment which was calculated as the number of children attending school that are between 7 and 11 years old divided by the total number of children that are between 7 and 11 years old in the municipality; and secondary school enrollment defined as the number of children attending school

\footnotetext{
${ }^{26}$ We have also computed an alternative measure where individuals whose land plots are in the top $50 \%$ most valuable plots are counted as "rich landowners," with very similar results. We do not report these results to save space.
} 
that are between 12 and 17 years old divided by the total number of children that are between 12 and 17 years old in the municipality. The descriptive statistics in Table 1 show that there is much more variation across municipalities in secondary school enrollment, motivating our focus on this measure (though we will also show results using primary school enrollment).

Figure 7 is similar to Figures 5 and 6 and maps the secondary enrollment data across the Cundinamarca municipalities. Darker colors now indicate higher enrollment. It is evident from this figure that enrollment is higher closer to Bogotá and particularly on the Sabana de Bogotá.

We also used the 1993 census to construct a measure of urbanization, defined as the proportion of the population in urban areas. The census reports urban population for each municipality so we simply divided this by the total population of the municipality. Each municipality has one urban area, the cabecera where the municipal government buildings are located (other sub-districts of the municipality are called veredas) so urban population is the population of the cabecera.

Finally, the 1993 census also provides an index of poverty, referred to as unsatisfied basic needs (which has the Spanish acronym NBI-Necesidades Básicas Insatisfechas) and used commonly in Colombia and in other Latin American countries. In this index, a household is counted as having unsatisfied basic needs if it meets any one of five different criteria. These are (1) inadequate dwelling, such as the floor is composed of soil or the house is made of precarious building materials. (2) The household's dwelling lacks basic services, such as piped water, sewers or toilets. (3) The household is overcrowded which is defined to be one where the number of people per bedroom is greater than 3. (4) The household is characterized by inadequate school attendance which is indicated by a child between 7 and 11 years old who does not attend school. (5) The household has high economic dependence, meaning that the head of the household has less than fourth grade education and has more than three dependents. The indicator we use is the proportion of households in a municipality with unsatisfied basic needs.

For the medium-term outcomes, we used data from the 1937 population census. While there are no data on educational enrollment in this census, we can measure the proportion of adults who were literate. We also calculated urbanization in 1937 in exactly the same way as we did in 1993. Finally, the 1937 census also records for each municipality the total number of buildings and also the number of buildings which lack access to electricity, water and sewage. We therefore constructed the fraction of buildings without access to all public services by combining these two pieces of information, which provides us with a measure of non-educational public good provision.

We use a variety of exogenous control variables in the regressions in order to ensure that our results are not driven by omitted differences in the quality or productivity of land. Our controls 
include altitude of the municipality (in meters above sea level), the distance of the municipality to Bogotá (in kilometers), area (in squared kilometers), average rainfall (in millimeters). All of these data were obtained from Instituto Geográfico Agustin Codazzi in Bogotá. Distance to Bogotá may be particularly important, since Figure 5 suggests that there are a number of municipalities near Bogotá that have relatively high land inequality. We check the robustness of our results to including high degree polynomials in distance to Bogotá that would capture any non-linear effect of this variable.

Finally, we also control for the year of foundation of a municipality (from Bernard and Zambrano, 1993). While the highlands of Cundinamarca were settled in the 16th century, much of the lower Western and Eastern slopes were only settled in the mid 19th century in a process of frontier expansion. This frontier expansion was associated with the spread of the coffee economy (see Rivas, 1946, or Palacios, 1980, for discussion) and the determination of property rights in land and the nature of the societies that formed in the 19th century may be quite different from those founded during the colonial period (see Jiménez, 1985, for a detailed treatment of one such municipality, Viotá). We include the foundation date in some of our regressions to control for this source of omitted variable bias.

\subsection{Descriptive Statistics and Correlations}

Table 1 shows descriptive statistics for our entire sample and also for subsamples created according to land gini and political concentration (both average values over the two dates and the subsamples were created by dividing the sample according to median values). A number of features are notable in this table. First, the land gini at the end of the 19th century was quite high, 0.65. Moreover, it still continues to be very high today (third row). The standard deviation of this variable indicates that there is considerable variation in the extent of land inequality within Cundinamarca. The same applies to the extent of political inequality. Also, as noted above, the outcome variables also show considerable variation, except primary school enrollment, which is very high in most municipalities, thus exhibits less variation than the other outcome variables.

Table 1 also shows descriptive statistics by dividing the sample into low and high land inequality areas (columns 2 and 3) and into low and high political concentration areas (columns 4 and 5). The comparison of columns 2 and 3 shows that all economic outcomes are better in high land inequality areas. For example, secondary school enrollment is $65 \%$ in high land inequality areas, whereas low land inequality areas have only $52 \%$ secondary school enrollment. In contrast, when we turn to political concentration, low political concentration areas have better economic 
outcomes. For example, secondary school enrollment is $60 \%$ in low political concentration areas and $56 \%$ in high political concentration areas. These differences are consistent with the patterns shown in Figures 3 and 4, and the regression analysis will show that these differences are relatively robust to controlling for a variety of geographic and other controls.

Table 2 describes our data further by showing the correlation matrix among our main historical explanatory variables, the land gini at the end of the 19th century, the overall land gini at the end of the 19th century, the contemporary land gini, the political concentration index and the overlap variable, as well as our main outcome variables. This table shows that there is a negative correlation between political and economic inequality, which is the opposite of the pattern that appears in the 19th-century US (where political inequality also appears to be higher in the more unequal South). This contrast between the US and Cundinamarca confirms the discussion in the Introduction. In any case, the correlation between the two variables is not very large (correlation coefficient -0.25), giving us an opportunity to determine the separate correlation between political and economic inequality and economic outcomes. Overlap is even less correlated with these two variables.

The outcome variables are also correlated with each other, though not very highly so. For example, the correlation between urbanization and primary school enrollment is only 0.23 . This implies that there is independent information in all of these outcome variables, and considerable independent variation in our basic inequality variables.

\section{The Inequality of Wealth: Cundinamarca and the United States}

As discussed in the Introduction, a recently-emerging consensus relates the current differences in economic outcomes between the United States and South America to 19th-century differences in inequality (especially land inequality). Was land more unequally distributed in Cundinamarca than in the United States in the 19th century? In this section, we will see that the answer to this question is more nuanced than typically presumed. Cundinamarca appears to be substantially more unequal than the Northern United States, but more equal than the US South.

To provide a comparison of land inequality between Cundinamarca and the United States in the 19th century, we compare our land inequality data (described above) with US microdata from the 1860 land census provided in the Gallman-Parker and Bateman-Foust samples. These data, which are downloadable from the Inter-university Consortium for Political and Social Research (ICPSR) website, comprise two famous random samples taken from the 1860 census. The Gallman-Parker sample contains variables recorded for 5,228 farms located in the major cotton- 
producing counties of the South (see, e.g., Schaefer and Schmitz, 1985, Schmitz and Schaefer, 1986). The farms were selected from the 1860 manuscript census schedules by a sample of all farms in 405 Southern counties which each produced over 1,000 bales of cotton in 1860. This resulted in a 1.67 percent sample of all farms in the major cotton-growing counties of the eleven states of the Confederacy. We use the data on the value of the farms in dollars. The BatemanFoust sample (see Bateman and Foust, 1974) contains demographic, occupational, and economic information for over 21,000 rural households in the northern US. The data were obtained from the agricultural and population schedules of the 1860 census and cover all households in a single township from each of 102 randomly-selected counties in sixteen northern states. We again use the data on the dollar value of farms. Together these datasets give us a picture of land distribution in both the northern and southern US in 1860.

Our calculations using these samples are reported in Table 3. In particular, we compute the land gini for individual states and for the North, the South and the entire United States. The picture that emerges from the comparison of the numbers in Table 3 to those in Table 1 is interesting. As expected, Northern US states are considerably more equal than Cundinamarca. For example, Connecticut has the lowest land gini of 0.34, compared to the land gini of 0.65 in Cundinamarca. However, contrary to the widespread notion that Latin America is substantially more unequal than the United States, all Southern states, except Florida, Georgia and the Carolinas, are more unequal than Cundinamarca. For example, the land gini in Louisiana is 0.83, considerably higher than that of Cundinamarca. The average land gini in the South is 0.72 , which is also greater than the gini for Cundinamarca, 0.65 .

\section{Inequality and Long-Run Development in Cundinamarca}

We now examine the consequences of wealth inequality, political concentration and overlap for long-run development outcomes. To do this we exploit the cross-sectional variation within the municipalities in Cundinamarca. Throughout the section, we estimate cross-sectional ordinary least squares (OLS) regressions of the following form

$$
y_{m}=\alpha g_{m}+\beta p_{m}+\gamma o_{m}+\mathbf{x}_{m}^{\prime} \boldsymbol{\delta}+u_{m}
$$

where $y_{m}$ is some measure of development in municipality $m, \mathbf{x}_{m}$ is a vector of covariates and $u_{m}$ is an error term, capturing all other omitted factors, with $E\left(u_{m}\right)=0$ for all $m$. In (2) the main objects of interest are the coefficients on the land gini, denoted by $g_{m}$, the extent of political concentration, denoted by $p_{m}$, and the degree of overlap, denoted by $o_{m}$, in municipality $m$. We 
report regressions in which each of these variables features separately and then together. We start by looking at the effect of these variables on contemporary outcomes and then turn to their effect on 1937 outcomes. A key concern in all of these regressions is omitted variable bias. For this reason, the vector $\mathbf{x}_{m}$ will control for a rich set of covariates, especially for measures of differences in land quality across municipalities.

\subsection{Contemporary Outcomes}

Tables 4 and 5 examine the relationship between our four contemporary outcome variables and historical land inequality, political concentration and overlap. Panel A of Table 4 is for secondary school enrollment, while Panel B is for primary enrollment. Column 1 shows the bivariate relationship between land gini and secondary school enrollment without any other controls. There is a strong positive association, indicating that municipalities that were more unequal at the end of the 19th century have higher levels of secondary school enrollment today. This relationship in column 1 is the same as that shown in Figure 3 in the Introduction. The coefficient estimate is equal to 0.61 , and is highly significant with a standard error of 0.09 . The $R^{2}$ of this bivariate regression is $30 \%$, indicating a large and significant correlation between historical land inequality and secondary schooling. As a different way of gauging the quantitative significance of this correlation, recall from Table 1 that the standard deviation of land gini is 0.10 in the entire Cundinamarca. The coefficient estimate implies that we expect a municipality with one standard deviation greater land gini than the mean to have approximately 0.06 percentage points higher secondary school enrollment. Relative to the mean of this variable in Cundinamarca, 0.58, this translates into a $10 \%$ increase, which is substantial.

The main threat to the interpretation of the relationship between land inequality and contemporary economic outcomes is that municipalities with greater inequality may have higher quality lands or other sources of higher incomes. While we cannot control for all possible sources of omitted variable bias, we can check the robustness of this correlation to a range of geographic controls that should capture differences in land quality. Column 2 attempts to do this by adding altitude, distance to Bogotá, amount of rainfall, and also the historical variable, the year of foundation of the municipality. After including these controls, there is still a positive association between the land gini and secondary schooling, though the coefficient is slightly smaller now, 0.48 (standard error $=0.10)$.

Column 3 looks at relationship between the political concentration index and secondary school enrollment. Here we see a statistically significant (though somewhat weaker) negative relationship, 
corresponding to the pattern shown in Figure 4 in the Introduction. The coefficient estimate, -0.36 , is highly significant with a standard error of 0.11 . The quantitative magnitude of this effect is also somewhat smaller than the magnitude associated with the land gini; the coefficient estimate implies that a municipality with a one standard deviation above the mean political concentration index tends to have 3.6\% lower secondary school enrollment in 1993. Column 4 demonstrates that this relationship is robust to including geographic controls and the magnitude of the effect is only slightly smaller, -0.35 (standard error $=0.10$ ), than in column 3 .

Columns 5 and 6 show that there is a negative but not always significant relationship between overlap and school enrollment. For example, without covariates, the relationship is insignificant, and it becomes marginally significant at $5 \%$ when the geographic controls are included.

Columns 7 and 8 look at the effect of land gini and the political concentration index when they are included together. Both variables continue to be significant, and together with the geographic controls they explain about $50 \%$ of the variation in secondary schooling across Cundinamarca municipalities.

Finally, in columns 9 and 10, we add further controls in order to deal with potential omitted variable concerns. Column 9 adds the contemporary land gini. Interestingly, this is also significant and positive, but the historical land gini continues to be positive and significant (coefficient $=$ 0.28 , standard error $=0.11$ ), while the political concentration index continues to be negative and significant $($ coefficient $=-0.22$, standard error $=0.11$ ).

Column 10 is the most demanding specification and adds a quartic in distance to Bogotá in order to flexibly control for differences in the quality of land plots that may be near Bogotá. In this column we also control for the best proxy for differences in land quality across municipalities, the average land value per square kilometer from the land censuses. The quartic in the distance to Bogotá is useful since Figure 5 showed that land inequality is higher in many of the municipalities that are near Bogotá. Average land value is the market's perception of differences in land quality at the end of the 19th century and should be a "sufficient statistic" for these differences. Moreover, differences in average land value will also indirectly control for differences in tax revenues across municipalities, a major source of revenue and thus of fiscal capacity of municipalities. ${ }^{27}$ The addition of these variables reduces the effect of the land gini to 0.16 (standard error $=0.10$ ), which is no longer significant at $5 \%$, but the effect of political concentration index remains unchanged

\footnotetext{
${ }^{27}$ We do not have data on current land values or average income differences across municipalities. Even if we had such data, it would not be appropriate to include these as controls in our regressions, since average income in a municipality is partly an outcome of education and public good provision, which we are attempting to explain with historical measures of economic and political inequality.
} 
and still significant at $5 \%$.

One concern may be that Cundinamarca is atypical and some unobserved heterogeneity is responsible for the positive relationship between land inequality and secondary school enrollment. In fact, the results in Panel A of Table 4 show not only a positive relationship between the historical land gini and secondary enrollments today, but also a positive association between contemporary land inequality and schooling. As a check for whether Cundinamarca is atypical in terms of the relationship between land inequality and schooling, we looked at the contemporaneous relationship between these two variables for all Colombian municipalities. ${ }^{28}$ Figure 8 shows the relationship between land gini today (2002) and secondary school enrollment in the whole Colombia. ${ }^{29}$ Consistent with the patterns for Cundinamarca, there is a positive relationship, and in fact the magnitude of this relationship is very similar to that we find in Cundinamarca. This gives us some confidence that the relationship within Cundinamarca is not an aberration, and whatever factors are responsible for the positive association between land inequality and education within Cundinamarca seem to be present when we look at the whole of Colombia.

Panel B repeats the same regressions as in Panel A with primary school enrollment. The overall pattern is the same, except that all of the variables are less significant than in Panel A, and both land gini and the political concentration index are no longer significant in column 10 when all of the controls, including the contemporary land gini and the quartic in distance to Bogotá are included. These weaker results probably reflect the fact that, as noted above, primary enrollment is already high in most municipalities.

Panel A of Table 5 looks at urbanization, which is a crude but useful proxy for overall development in a municipality and to an index of poverty constructed from the national census based on unsatisfied basic needs of a family as described in the data section. The results in this table are broadly similar. There is a positive effect of the land gini on urbanization, though this effect becomes insignificant in columns 9 and 10. The relationship between political concentration and urbanization is also negative and significant when we do not include additional controls, but

\footnotetext{
${ }^{28}$ We cannot look at the relationship between historical land gini and schooling for the whole of Colombia, since the historical data on land distribution are only available for Cundinamarca.

${ }^{29}$ In particular, Figure 8 shows the relationship excluding "outliers," that is municipalities with the highest $2.5 \%$ and lowest $2.5 \%$ values for the land gini. The relationship is very similar without excluding these extreme values, though the basic pattern in the figure is harder to see. The same results can be seen from simple regression analysis. Within Cundinamarca, a regression of secondary school enrollments on contemporary land gini gives a coefficient of 0.67 (standard error $=0.09$ ). For the entire Colombia, the same regression leads to a coefficient of 0.57 (standard error $=0.04$ ) without excluding municipalities with extreme values of the gini, and to a coefficient of 0.63 (standard error $=0.05$ ) when these extreme values are dropped. The coefficients are very similar when we include the standard geographic controls. In addition, including a full set of department (region) fixed effects leaves the relationship between the land gini and secondary school enrollment essentially unchanged (coefficient $=0.53$, standard error $=0.04$ ).
} 
becomes insignificant in columns 9 and 10 .

When we turn to our index of poverty in Panel B of Table 5, the results are more robust. In all columns, there is a negative and significant relationship between the land gini and poverty and a positive and significant relationship between the political concentration index and poverty. In particular, even in column 10, where we control for a quartic in distance to Bogotá and for average land values, a higher land gini is associated with lower poverty and higher political concentration is associated with significantly higher poverty.

Overall, we conclude that, contrary to the conventional wisdom about the nature of longrun development in Latin America, there is no evidence that higher land inequality is related to bad economic outcomes. On the contrary, in most of our specifications there is a positive and significant relationship between land inequality and good economic outcomes. Instead, there seems to be a fairly robust negative relationship between political inequality on the one hand and education and poverty on the other. The results in Tables 4 and 5 also indicate that the comparatively worse development in municipalities with lower land inequality and higher political concentration might be working partly through lower provision of public goods, such as schooling, in these areas. ${ }^{30}$

\subsection{Medium-term Outcomes from the 1937 Census}

We next turn to the effect of the land gini, political concentration and overlap from the late 19th century on medium-term (1937) outcomes. This exercise is interesting for a number of reasons. First, looking at the 1937 outcomes is a useful robustness check on the results presented in Tables 4 and 5. Second, the effect on medium-term outcomes might be informative about the mechanisms through which economic and political inequality might be affecting economic development.

The results with the 1937 outcomes are presented in Tables 6 and 7. In all cases, we report regressions of the form (2) again, with the only difference that the different dependent variables are now those that are available in the 1937 census.

Panel A of Table 7 examines the impact of the land gini, political concentration and overlap

\footnotetext{
${ }^{30}$ We tried a number of different identification strategies to estimate the causal effect of political concentration on development outcomes using instrumental variables. All of these tried to exploit the idea that political concentration represented the legacy of the political monopoly of colonial elites. We first looked directly at the colonial elite, that is, all of the Spaniards granted encomiendas in the 16th century and those working for the colonial state in 1794, and matched their last names to the names of mayors at the end of the 19th century. Even though there were a number of matches, this variable turned out not to have much predictive power for political concentration. We then looked directly at where the grants of encomiendas were and at the density of tributary Indian population in the 16 th century, but we found these to be uncorrelated with political concentration. We finally looked more generally at other measures of the colonial legacy such as the presence of the colonial state, measured by the location of tax collectors or state monopolies. Again this turned out to be uncorrelated with political concentration.
} 
on adult literacy. A greater land gini is associated with higher literacy in column 1, but this relationship disappears once we control for the standard geographic covariates in column 2 . In contrast, there is a robust negative relationship between political concentration and literacy with or without the covariates (shown in columns 3 and 4 ).

Columns 5 and 6 show that although the estimated coefficient on overlap is negative, it is not statistically significant. Columns 7,8 and 9 include the land gini and the political concentration index together, and column 9 also includes the quartic in the distance to Bogotá and our proxy for differences in land quality, average land value. In all cases, there is no relationship between literacy and the land gini, but there is a robust and statistically significant negative effect of political concentration on literacy. Consequently, we conclude that the negative effect of higher political inequality on medium-term educational outcomes is relatively robust.

Panel B of Table 6 examines urbanization in 1937. The results here are similar to those for urbanization in 1993. The land gini has a significant positive coefficient. Political concentration and overlap are also significant and have the same sign as in the other tables, though they become less significant when entered together with the land gini. When all of these variables, as well as the quartic in distance to Bogotá and average land values, are included together in columns 7, 8, and 9, the results become insignificant, though the quantitative effect of political concentration index is similar to earlier columns.

Finally Table 7 looks at a direct measure of public good provision for 1937, the fraction of buildings without access to public services. This variable is informative about whether the effects of land inequality and political concentration might be working by affecting the extent of public good provision in different municipalities. Column 1 shows that greater land inequality is associated with better outcomes (greater access to public services). This effect remains statistically significant when covariates are added in column 2, though the size of the coefficient falls by one half.

Columns 3 and 4 show that there is a negative relationship between political concentration and public good provision in 1937 with or without covariates. In this case, the magnitude of the coefficient is also relatively insensitive to whether or not covariates are included. Columns 5 and 6 then show that higher overlap is also significantly correlated with worse outcomes. However, this effect is not robust to the inclusion of economic and political inequality. The effect of the land gini continues to be negative and significant in columns 7 and 8 , but not in column 9 . The coefficient on political concentration index remains similar even with the extended set of controls, though because of the larger standard errors, it is only significant at $10 \%$. 
Overall, the results from the 1937 census are broadly consistent with the patterns for contemporary outcomes and indicate that municipalities with greater economic inequality fare better in terms of economic outcomes and public good provision, while those with greater political inequality do worse.

\subsection{Corroborating the Mechanism}

The results presented so far are the opposite of much of the recent literature on underdevelopment in Latin America and also inconsistent with the literature in economics emphasizing the negative effects of inequality on economic growth working through either credit market mechanisms or political economy. In the Introduction, we suggested a potential interpretation for these patterns based on Bates's (1981) seminal work on Africa. Bates showed how greater land inequality in Kenya relative to Ghana led to better policies and outcomes, because it prevented politicians from pursuing highly distortionary policies, leading to the collapse of agricultural markets in many African countries. We argued that in weakly institutionalized polities such as post-colonial Africa or 19th-century Colombia, economic inequality may be a useful counterbalance against the unchecked power of political elites.

Is there any way to corroborating this story? In the next section, we will document that politicians in Cundinamarca indeed appear to have used their political power to amass very significant wealth. Another way of checking our story is to distinguish between the land gini (land inequality among landowners) and the overall land gini (inequality among all families) as described in Section 3. In Table 8 we repeat our main regressions including the land gini together with the overall land gini. We only show the specifications with the standard geographic controls and the specification with the extended set of controls (quartic in distance to Bogotá and average land value). In all of the regressions, we drop the overlap measure, since it is almost always insignificant and not central to this discussion. Panel A of the table shows the long-term outcomes, while Panel B is for medium-term outcomes.

The overall picture that emerges is very interesting. In all cases, a higher land gini is associated with better outcomes both in the long run and in the medium run. In contrast, overall land inequality has the opposite sign, though it is typically insignificant. Political concentration maintains its negative effect on long-run and medium-run outcomes and is typically significant. Therefore, the results in this table suggest that what matters is not overall inequality or poverty (as would be the case in models with credit market constraints), but the extent of inequality among landowners. This is consistent with the interpretation that better economic outcomes 
emerge when there exists a group of significant landowners that can counterbalance the effect of politicians.

\section{Political Power and Land Accumulation}

The evidence presented so far established a range of interesting correlations between historical variables and the economic development of different municipalities in Cundinamarca. While we are unable to conclude that these correlations correspond to the causal effects of economic and political inequality on economic development, they suggest some interesting patterns that need to be investigated further. One possible area of study is to see whether various first-order mechanisms via which political power might affect economic outcomes are present. In particular, is it the case that individuals with greater political power are able to use this for their own economic benefit?

The data suggests that both for 1879 and 1890 landowners with political power have on average more valuable land plots than non-politician landowners. For 1879, landholdings of a nonpolitician landowner were worth $\$ 1770$ on average while the average was $\$ 3022$ for landowning politicians. The corresponding figures for 1890 are $\$ 2915$ and $\$ 5726$ respectively. The same pattern applies when we look at the percentage change in land value between the two catastros. While the value of land for non-politician landowners increased on average $99 \%$ between 1879 and 1890, plots for politicians increased, on average, $209 \% .31$

More interesting than this cross-sectional comparison would be to investigate whether politicians increased their land holdings (or the value of their land) more than other landowners and by how much. We are able to do this by using our micro data. In particular, we restrict the sample to landowners that were present in both censuses and investigate whether those that have held political power saw the value of their lands increase. We measure the extent of political power by the number of years that an individual was in power between 1879 and 1890 (thus creating a continuous measure of political power). We denote this measure by $n_{m i}$, the number of years that individual $i$ was in power in municipality $m$. We start with the simple OLS regression of the form

$$
\Delta v_{m i}=\lambda n_{m i}+\mathbf{x}_{m}^{\prime} \boldsymbol{\mu}+\varepsilon_{m i}
$$

where the dependent variable $\Delta v_{m i}$ is the percentage change in the value of land held by landowner $i$ in municipality $m$. The coefficient of interest is $\lambda$, which measures the relationship between the number of years the politician has been in power, $n_{m i}$, and the change in land value. Once again

\footnotetext{
${ }^{31}$ Since we do not have a price index for this period, all of these changes are nominal.
} 
$\mathbf{x}_{m}$ refers to a vector of control variables, all of them defined at the municipality level (since we do not observe any individual characteristics). Also $\varepsilon_{m i}$ is an error term with the usual properties.

The results of this exercise are reported in the first three columns of Table 9 . The first column does not include any geographic controls. The second column includes the standard geographic controls, while the third column also adds a full set of municipality fixed effects (so that identification comes only by comparing politicians and landowners within each municipality). Panel A of this table reports the results of this regression on a balanced panel consisting of 6391 individuals that were landowners both in 1879 and in 1890. When we include geographic controls, the sample is down to 6156 landowners. Columns 1-3 show that one more year in power is associated with approximately 50\% higher land values, which is a very large effect. The estimates in all three columns are highly statistically significant. This estimate suggests that an individual that remains in power for four years increases the value of his land holdings by $200 \%$ relative to other landowners. This is truly a large effect and shows how important political power appears to have been in 19th century Cundinamarca.

Panel B of Table 9, on the other hand, focuses on within-politician variation, and restricts the sample to a balanced panel of individuals that were landowners in both states and a politician at some date in-between. This leaves us with a sample of 560 individuals, out of which 32 are lost when we restrict the sample to municipalities for which we have all the geographic controls. In this case again, there is a positive association between number of years in power and the change in land value in both columns, though this relationship is now only significant at $10 \%$. While the relationship is slightly imprecise, the magnitude of the effect continues to be large. An additional year in power is associated with an additional increase in land value of 29 percentage points. ${ }^{32}$

The effect of political power on land values may be different for different politicians. For example, some politicians may be more corrupt than others, or some politicians may focus their energy in self-enrichment in other spheres of economic life. To investigate this issue we estimate standard quantile regressions (Koenker and Bassett, 1978). In particular, we report regressions from the quantile regressions of the form:

$$
\Delta v_{m i}=\lambda(\tau) n_{m i}+\mathbf{x}_{m}^{\prime} \boldsymbol{\mu}(\boldsymbol{\tau})+\varepsilon_{m i}(\tau)
$$

where $\tau$ refers to the quantile in question. This regression estimates a separate vector of coefficients, $\lambda(\tau)$ and $\boldsymbol{\mu}(\boldsymbol{\tau})$, for each quantile, indicating how political power has different effects

\footnotetext{
${ }^{32}$ In some sense, the difference in the magnitudes between the two Panels corresponds to the difference in "intensive" and "extensive" margins. Panel B only exploits the intensive margin, the within-politician variation, and thus has a lower effect of an additional year in power on land values, whereas Panel A includes the sum of the intensive and extensive margins.
} 
depending on the (residual) distribution of changes in land value of the politician. Given the moderate number of observations we have (approximately 6000 in Panel A and only 528 in Panel B), we look at non-extreme quantiles, $0.15,0.25, \ldots, 0.85$.

Consistent with our expectations, we find much larger effects of political power on land value changes at higher quantiles. For example, in Panel A, while the effect at the median is 0.27 (standard error $=0.02$ ), the effect at the 75 th percentile is 0.65 (standard error $=0.04$ ) and at the 85th percentile it is even significantly larger, 1.02 (standard error $=0.0 .7$ ). These results are also plotted in Figure 9, which shows the monotonically increasing effect as we look at higher quantiles. The results in Panel B confirm the same pattern.

Our interpretation of these is that those with political power are able to amass greater economic wealth, either by acquiring more land or by increasing the value of their land, and this effect is especially pronounced when we look at heterogeneity among landowners. Naturally, these microdata regressions do not establish causality either, and part of the effect may reflect unobserved heterogeneity (for example, those with greater ability being selected into politics and also able to increase the value of their lands). Nevertheless, we find these results encouraging for hypotheses emphasizing the importance of political power and political inequality. In addition, we believe these results are very consistent with the idea that in places where their power was not checked by landed elites, politicians were able to use their power in socially inefficient ways, possibly by expropriating land and or by targeting public services, such as roads, to increase the value of the land they held.

\section{The Dynamics of Wealth and Political Power}

As a final check on the relationship between political power and economic wealth, we also investigate whether politicians are likely to become landowners and how this compares to the likelihood of economically wealthy individuals becoming politicians. In particular, let $r_{i t} \in\{0,1\}$ be an indicator for whether individual $i$ is a rich landowner at time $t$, while $p_{i t} \in\{0,1\}$ is an indicator for whether individual is a politician at time $t$. We also use $p_{i t}^{o}=1$ to denote an individual who is a politician but not a rich landowner at time $t$, and $r_{i t}^{o}=1$ to denote a rich landowner at time $t$ who is not a politician. Finally, $l_{i t}=1$ denotes an individual who is neither a rich landowner nor a politician.

We are interested in the likelihood that a politician who was not a rich landowner becomes a rich landowner, which can be expressed as $\operatorname{Pr}\left[r_{i t+1} \mid p_{i t}^{o}\right]$. However, rather than looking at this conditional probability, it is more natural and informative to normalize this with the probability 
that an individual who is neither a politician or a rich landowner becomes a rich landowner, $\operatorname{Pr}\left[r_{i t+1} \mid l_{i t}\right]$. Consequently, the first measure of interest is

$$
\frac{\operatorname{Pr}\left[r_{i t+1} \mid p_{i t}^{o}\right]}{\operatorname{Pr}\left[r_{i t+1} \mid l_{i t}\right]}
$$

Our main interest is to compare this ratio to the likelihood that a rich landowner who was not a politician initially became a politician, which is defined similarly as

$$
\frac{\operatorname{Pr}\left[p_{i t+1} \mid r_{i t}^{o}\right]}{\operatorname{Pr}\left[p_{i t+1} \mid l_{i t}\right]}
$$

Finally, we can also look at

$$
\frac{\operatorname{Pr}\left[r_{i t+1} \mid r_{i t}^{o}\right]}{\operatorname{Pr}\left[r_{i t+1} \mid l_{i t}\right]} \text { and } \frac{\operatorname{Pr}\left[p_{i t+1} \mid p_{i t}^{o}\right]}{\operatorname{Pr}\left[p_{i t+1} \mid l_{i t}\right]}
$$

to measure persistence in the landowning and political status again for comparison. ${ }^{33}$

Table 10 shows $2 \times 2$ matrices of these ratios for Cundinamarca and for the nine provinces (which are made up of the municipalities we studied until now). We compute the standard errors for these ratios by bootstrapping. ${ }^{34}$ The results in Table 10 show that in Cundinamarca as a whole and in eight out of the nine provinces, the probability of transitioning from being a politician to landowner is greater than the probability of transitioning from being a landowner to a politician (in both cases normalized by the probability of transition of a non-landowner non-politician). Moreover, this difference is statistically significant (at $5 \%$ or less) for the whole of Cundinamarca and for the four larger provinces. This finding is also consistent with our interpretation that political power is important in obtaining economic rents and resources. In contrast, there seems to be a smaller role of wealth in enabling individuals to become politicians. This pattern therefore strengthens our overall conclusion that a more systematic study of the consequences of political power and of political inequality on economic outcomes and economic development is necessary. ${ }^{35}$

\section{Conclusions}

What is the effect of economic inequality on long-run economic development? This question is central for many theories of comparative development and has gained further attention by recent

\footnotetext{
${ }^{33}$ There are naturally many other ratios of conditional probabilities we can look at, for example,

$$
\frac{\operatorname{Pr}\left[r_{i t+1} \mid r_{i t}\right]}{\operatorname{Pr}\left[r_{i t+1} \mid l_{i t}\right]} \text { and } \frac{\operatorname{Pr}\left[r_{i t+1} \mid p_{i t}\right]}{\operatorname{Pr}\left[r_{i t+1} \mid l_{i t}\right]},
$$

but the four that we focus on are sufficiently informative for our purposes.

${ }^{34}$ The standard errors were computed via non-parametric bootstrapping with 500 replications.

${ }^{35}$ One caveat is that when we look at individuals that are both landowners and politicians in 1879 , they have the highest probability of (still) being a landowner or remaining a politician in 1890 .
} 
emphasis from Engerman and Sokoloff (1997) and others that the roots of the different economic performances of the north and south of the American continent are in their different levels of economic inequality in the 19th century. Most existing investigations of this question look at cross-country data (or cross-state and cross-village data) and do not distinguish between economic and political inequality. However, many theories suggest that economic inequality is likely to lead to political inequality, so that political power should be concentrated in the hands of those who are rich, while other equally plausible theories suggest that political inequality, the concentration of political power in the hands of a few, is likely to lead to economic inequality as the politicallypowerful use politics to become richer. Consequently, we expect the Latin American societies in the 19th century not only to be economically more unequal, but also to feature greater levels of concentration of political power in the hands of a few. Nevertheless, neither existing theoretical discussions nor existing empirical studies distinguish the potentially different roles of economic and political inequality. Understanding whether it is economic or political inequality that matters for economic development is important both to understand the mechanics of long-run development and also because outside of the Americas, there are instances of societies with relatively equal distributions of economic resources but high degrees of political inequality (e.g., many countries in the sub-Saharan Africa and East Asia).

In this paper, we used unique data from 19th century Colombia to undertake a first investigation of the relative and potentially distinct roles of economic and political inequality on long-run development. Using land censuses (catastros) from 1879 and 1890, we constructed measures of land inequality (land gini) and we collected information on the identity of mayors in each of the municipalities in Cundinamarca from which we constructed an index of political concentration.

Our data indeed confirm that Cundinamarca is more unequal than the Northern United States in the 19th century. However, perhaps somewhat surprisingly, we find that Cundinamarca is more equal than the US South. Even more surprising, we find that across Cundinamarca municipalities there is a negative association between political and economic inequality. Though perhaps political inequality can be conceptualized and measured in other ways, what we find certainly suggests the conventional wisdom is too simplistic. Moreover, and again very differently from the recentlyemerging consensus about the sources of comparative development within the Americas, we find a positive association between economic (land) inequality and long-run development. Municipalities with greater land inequality are those that supply more public goods and are more educated and urbanized today. In contrast, we find a relatively robust negative relationship between political inequality and economic outcomes. We also showed that politically powerful individuals appear 
to have been much more likely to become landowners and to have increased the value of their lands substantially.

Our interpretation of these results is that in weakly institutionalized polities, such as 19thcentury and 20th-century Colombia, economic inequality may be a useful counterbalance against the most rapacious policies that may be pursued by political elites. This interpretation is consistent both with the negative effect of political concentration (inequality) on long and medium-term outcomes in Cundinamarca, with the evidence presented by Bates (1981) for Africa, and with the additional results we presented above, suggesting that it is inequality among landowners, not overall inequality, that has the positive effect on various economic outcomes. Although this interpretation is consistent with our findings and plausible in view of the experiences of other countries with weakly institutionalized polities, it is very different from the conventional wisdom in the studies of underdevelopment in Latin America and from the conclusions of the recent economic literature focusing on the effects of inequality on economic growth. Nevertheless, our results do not provide a direct test of this interpretation and whether this perspective is useful for understanding the relationship between inequality and economic growth and the development path of Latin America remains an open research question.

It should also be emphasized that all of the results presented in this paper, striking though they may be, are historical correlations. While we control for a variety of geographic factors and other municipality characteristics, we cannot be sure that these associations correspond to the causal effect of land inequality and political concentration on long-run economic development. Nevertheless, given the robustness and the magnitudes of these patterns, they call for more nuanced theories of comparative development. At the very least, theories that emphasize the importance of economic inequality should be able to explain these robust correlations. Therefore, irrespective of whether the correlations presented here have a causal component and of whether the interpretation we offer is the correct explanation of the patterns observed in Cundinamarca, the evidence strongly suggests that in addition to the emphasis on economic inequality, there should be more research to understand the effects of politics and political inequality on economic outcomes in comparative development. 


\section{References}

Acemoglu, Daron (2007a) "Oligarchic vs. Democratic Societies," forthcoming Journal of the European Economic Association.

Acemoglu, Daron (2007b) "Modelling Inefficient Institutions," in Richard Blundell, Whitney Newey and Torsten Persson eds. Advances in Economics and Econometrics, 3 Volumes, Ninth World Congress of the Econometric Society, New York: Cambridge University Press.

Acemoglu, Daron and James A. Robinson (2000a) "Political Losers as a Barrier to Economic Development," American Economic Review, 90, 126-130.

Acemoglu, Daron and James A. Robinson (2000b) "Why Did the West Extend the Franchise? Democracy, Inequality and Growth in Historical Perspective," Quarterly Journal of Economics, 115, 1167-1199.

Acemoglu, Daron and James A. Robinson (2006a) "Economic Backwardness in Political Perspective," American Political Science Review, 100, 115-131.

Acemoglu, Daron and James A. Robinson (2006b) "Persistence of Power, Elites and Institutions," NBER Working Paper \#12108.

Acemoglu, Daron, James A. Robinson and Thierry Verdier (2004) "Kleptocracy and Divide and Rule: A Theory of Personal Rule," Journal of the European Economic Association, 2, 162-192.

Acemoglu, Daron, Davide Ticchi and Andrea Vindigni (2006) "Emergence and Persistence of Inefficient States" NBER Working Paper \#12748.

Aghion, Philippe, Eva Caroli, and Cecilia Garcia-Peñalosa (1999) "Inequality and Economic Growth: The Perspective of the New Growth Theories," Journal of Economic Literature, $37,1615-1660$.

Alesina, Alberto and Roberto Perotti (1996) "Income Distribution, Political Instability and Investment," European Economic Review, 40, 1203-1225.

Alesina, Alberto and Dani Rodrik (1994) "Distributive Politics and Economic Growth," Quarterly Journal of Economics, 109, 465-490.

Banerjee, Abhijit and Esther Duflo (2003) "Inequality and Growth: What can the Data Say?" Journal of Economic Growth, 8, 267-299.

Banerjee, Abhijit and Andrew F. Newman (1993) "Occupational Choice and the Process of Development," Journal of Political Economy, 101, 274-298. 
Banerjee, Abhijit and Rohini Somanathan (2006) "Political Economy of Public Goods: Some Evidence from India," Unpublished, MIT Department of Economics.

Barro, Robert J. (1997) The Determinants of Economic Growth: A Cross-Country Empirical Study, Cambridge: MIT Press.

Barro, Robert J. (2000) "Inequality and Growth in a Panel of Countries," Journal of Economic Growth, 5, 5-32.

Bateman, Fred, and James D. Foust (1974) "A Sample of Rural Households Selected From the 1860 Manuscript Censuses," Agricultural History, 48, 75-93.

Bates, Robert H. (1981) Markets and States in Tropical Africa, Berkeley: University of California Press.

Benabou, Roland (1996) "Inequality and Growth," NBER Macroeconomics Annual, 11-73.

Benabou, Roland (2000) "Unequal Societies: Income Distribution and the Social Contract," American Economic Review, 90, 96-129.

Benjamin, Dwayne, Loren Brandt and John Giles (2006) "Inequality and Growth in Rural China: Does Higher Inequality Impede Growth?" Unpublished, Department of Economics, University of Toronto.

Bergquist, Charles W. (1978) Coffee and conflict in Colombia, 1886-1910, Durham: Duke University Press.

Bernard, Olivier and Fabio Zambrano (1993) Ciudad y Territorio: El Proceso de Poblamiento en Colombia, Bogotá: Academia de Historia de Bogotá.

Bertrand, Marianne, Francis Kramarz, Antoinette Schoar and David Thesmar (2006) "Politically Connected CEOs and Economic Outcomes: Evidence from France," Unpublished.

Bond, Philip, William Barndt, John Gerring and Carola Moreno (2005) "Democracy and Growth: A Historical Perspective," World Politics, 57, 323-364.

Bourguignon, François and Thierry Verdier (2000) "Oligarchy, democracy, inequality and growth," Journal of Development Economics, 62, 285-313.

Bushnell, David (1971) "Voter Participation in the Colombian Election of 1856," Hispanic American Historical Review, 51, 237-249.

Bushnell, David (1993) The Making of Modern Colombia: A Nation in Spite of Itself, Berkeley: University of California Press.

Camacho Roldán, Salvador (1892) "Catastro del Estado de Cundinamarca, 1868," in Escritos Varios de Salvador Camacho Roldán, Volume 1, Bogotá: Librería Colombiana. 
Christie, Keith H. (1978) "Antioqeño Colonization in Western Colombia: A Reappraisal," Hispanic American Historical Review, 58, 260-283.

Christie, Keith H. (1979) "Gamonalismo in Colombia: An Historical Overview," North/South: Canadian Journal of Latin American Studies, 4, 42-59.

Christie, Keith H. (1986) Oligarcas, campesinos y política en Colombia: aspectos de la historia socio-política de la frontera antioqueña, Bogotá: Universidad Nacional de Colombia.

Coatsworth, John H. (1998) "Economic and Institutional Trajectories in Nineteenth Century Latin America," in John H. Coatsworth and Alan M. Taylor eds. Latin America and the World Economy since 1900, Cambridge: Harvard University Press.

Coatsworth, John H. (2005) "Structures, Endowments, and Institutions in the Economic History of Latin America," Latin American Research Review, 40, 126-144.

Colmenares, Germán (1973) Historia Economica y Social de Colombia, 1537-1719, Bogotá: Tercer Mundo Editores.

Cruz Santos, Abel (1965) Economía y hacienda pública, 2 Volumes, Bogotá: Ediciones Lerner.

Deas, Malcolm (1971) "Algunas Notas sobre la Historia del Caciquismo en Colombia," Revista del Occidente, 127, 118-140.

Deas, Malcolm (1977) "A Colombian Coffee Estate: Santa Bárbara, Cundinamarca, 18701912," in Kenneth Duncan and Ian Rutledge eds. Land and labour in Latin America : essays on the development of agrarian capitalism in the nineteenth and twentieth centuries, New York: Cambridge University Press.

Deas, Malcolm (1993) Del poder y la gramática: y otros ensayos sobre historia, política y literatura colombianas, Santafé de Bogotá: Tercer Mundo Editores.

Delpar, Helen (1981) Red against blue: the Liberal Party in Colombian politics, 1863-1899, Tuscaloosa: University of Alabama Press.

Easterly, William (2007) "Inequality does cause underdevelopment: Insights from a New Instrument," forthcoming, Journal of Development Economics.

Engerman, Stanley L. and Kenneth L. Sokoloff (1997) "Factor Endowments, Institutions, and Differential Growth Paths among New World Economies," in Stephen Haber ed. How Latin America Fell Behind, Stanford: Stanford University Press.

Engerman, Stanley L. and Kenneth L. Sokoloff (2005) "The Evolution of Suffrage Institutions in the New World," Journal of Economic History, 65, 891-921. 
Estado de Cundinamarca (1859) Los doce Códigos del Estado de Cundinamarca, Bogotá: Echeverría.

Estado de Cundinamarca (1889) Ordenanzas del departamento de Cundinamarca: expedidas por la asamblea de 1888 y códigos, de policía y político municipal seguidos de algunas leyes nacionales y decretos del poder ejecutivo, Bogotá: Imprenta de la Luz, 1889.

Faccio, Mara (2006) "Politically Connected Firms," American Economic Review, 96, 369386.

Fisman, Raymond (2001) "Estimating the Value of Political Connections," American Economic Review, 91, 1095-1102.

Forbes, Kristen J. (2000) "A Reassessment of the Relationship between Inequality and Growth," American Economic Review, 90, 869-887.

Galor, Oded and Joseph Zeira (1993) "Income Distribution and Macroeconomics," Review of Economic Studies, 40, 35-52.

Galor, Oded, Omer Moav and Dietrich Vollrath (2006) Inequality in Land Ownership, the Emergence of Human Capital Promoting Institutions and the Great Divergence,"

Gilbert, Dennis L. (1977) The oligarchy and the old regime in Peru, Ithaca: Cornell University Press.

Gomez, Fernando (1969) "Análisis de los Censos de Población del Siglo XIX en Colombia," Tesis de Grado, Bogotá, Universidad de los Andes.

Gutiérrez, Rufino (1920) Monografías, Bogotá: Imprenta nacional.

Jiménez, Michael F. (1985) "The limits of export capitalism: economic structure, class and politics in a Colombian coffee municipality, 1900-1930," Unpublished Ph.D. Dissertation, Department of History, Harvard University.

Johnson, Lyman L. (1994) "The Distribution of Wealth in Nineteenth Century Buenos Aires Province," in Kenneth J. Adrien and Lyman L. Johnson eds. The Political Economy of Spanish America in the Age of Revolution, Albuquerque: University of New Mexico Press.

Johnson, Simon and Todd Mitton (2003) "Cronyism and capital controls: Evidence from Malaysia," Journal of Financial Economics, 67, 351-382.

Jones, Alice H. (1980) Wealth of a nation to be: the American colonies on the eve of the Revolution, New York: Columbia University Press.

Khwaja, Asim I. and Atif Mian (2005) "Do Lenders Favor Politically Connected Firms? Rent Provision in an Emerging Financial Market," Quarterly Journal of Economics, 120, 13711411. 
Koenker, Roger and Gilbert Bassett (1978) "Regression Quantiles", Econometrica, 46, 33-50.

LeGrand, Catherine (1986) Frontier expansion and peasant protest in Colombia, 18501936, Albuquerque: University of New Mexico Press.

Lizzeri, Alessandro and Nicola Persico (2004) "Why Did the Elites Extend the Suffrage? Democracy and the Scope of Government, With an Application to Britain's "Age of Reform," Quarterly Journal of Economics, 119, 707-765.

Margo, Robert A. (1990) Race and schooling in the South,1880-1950: an economic history, Chicago: University of Chicago Press.

Mazzuca, Sebastián and James A. Robinson (2006) "Political Conflict and PowerSharing in the origins of Modern Colombia," NBER Working Paper \#12099.

McCreery, David (1994) Rural Guatemala, 1760-1940, Stanford: Stanford University Press.

McGreevey, William P. (1970) An Economic History of Colombia, New York: Cambridge University Press.

Melo, Jorge Orlando (1996) Historia de Colombia: La Dominación Española, Bogotá: Biblioteca Familiar.

Meltzer, Allan H. and Scott F. Richard (1981) "A Rational Theory of the Size of Government," Journal of Political Economy, 89, 914-927.

Murphy, Kevin J., Andrei Shleifer and Robert W. Vishny (1989) "Income Distribution, Market Size and Industrialization," Quarterly Journal of Economics, 104, 537-564.

Nugent, Jeffery B. and James A. Robinson (2002) "Are Endowments Fate?" CEPR Discussion Paper \#3206.

Paige, Jeffrey M. (1997) Coffee and Power: Revolution and the Rise of Democracy in Central America, Harvard University Press; Cambridge.

Palacios, Marco (1980) Coffee in Colombia, 1850-1970: an economic, social, and political history, New York: Cambridge University Press.

Palacios, Marco (1981) "La Propriedad Agraria en Cundinamarca, 1880-1970: Un Esbozo sobre la Sociedad de las Tierras Templadas," Unpublished, El Colegio de México.

Pardo Umaña, Camilo (1946) Las Haciendas de la Sabana, Editorial Kelly: Bogotá.

Park, James W. (1985) Rafael Núñez and the politics of Colombian regionalism, 1863-1886, Baton Rouge: Louisiana State University Press. 
Parsons, James J. (1949) Antioqueño colonization in western Colombia, Berkeley: University of California Press.

Perotti, Roberto (1996) "Growth, Income Distribution, and Democracy: What the Data Say," Journal of Economic Growth, 1, 149-187.

Persson, Torsten and Guido Tabellini (1994) "Is Inequality Harmful for Growth?" American Economic Review, 84, 600-621.

Persson, Torsten and Guido Tabellini (2006) "Democratic capital: The nexus of political and economic change," NBER Working Paper \#12175.

Posada-Carbó, Eduardo (1997) "The Limits of Power: Elections under the Conservative Hegemony in Colombia, 1886-1930," Hispanic American Historical Review, 77, 245-279.

Ramcharan, Rodney (2006) "Inequality and Redistribution: Evidence from US Counties and States, 1890-1930," Unpublished, International Monetary Fund.

Rivas, Medardo (1946) Los trabajadores de tierra caliente, Bogotá: Ministerio de Educación de Colombia.

Robinson, James A. and Miguel Urrutia eds. (2007) Economía Colombiana del Siglo XX: Un Análisis Cuantitativo, Bogotá and México D.F.: Fondo de Cultura Económica.

Safford, Frank R. (1972) "Social Aspects of Politics in Nineteenth Century Spanish America: New Grenada, 1825-1850," Journal of Social History, 5, 344-370.

Safford, Frank R. (1974) "Bases for Political Alignment in Early Independent Spanish America," in Richard Graham ed. New Approaches to Latin American History, Austin: University of Texas Press.

Safford, Frank R. and Marco Palacios (2001) Colombia: Fragmented land, Divided society, New York: Oxford University Press.

Schaefer, Donald and Mark Schmitz (1985) "The Parker-Gallman Sample and Wealth Distributions for the Antebellum South: A Comment," Explorations in Economic History, 22, $220-226$.

Schmitz, Mark and Donald Schaefer (1985) "Using Manuscript Census Samples to Interpret Antebellum Southern Agriculture," Journal of Interdisciplinary History, 17, 399-414.

Schwartz, Stuart B. (1996) "The Landed Elite," in Louisa Schell Hoberman and Susan Migden Socolow eds. The Countryside in Colonial Latin America, Albuquerque: University of New Mexico Press.

Solberg, Carl E. (1969) "A Discriminatory Frontier Land Policy: Chile, 1870-1914," The Americas, 26, 115-133. 
Stein Stanley J. and Barbara H. Stein (1970) The Colonial Heritage of Latin America, New York: Oxford University Press.

Stone, Samuel Z. (1990) The Heritage of the Conquistadors: ruling classes in Central America from the Conquest to the Sandinistas, Lincoln: University of Nebraska Press.

Uribe-Uran, Victor (2000) Honorable Lives: Lawyers, Families and Politics in Colombia, 1780-1850, Pittsburgh: University of Pittsburgh Press.

Villamarin, Juan A. (1975) "Haciendas en la Sabana de Bogotá, Colombia, en la Época Colonial: 1539-1810," in Enrique Florescano ed. Haciendas, Latifundios y Plantaciones en América Latina, Mexico: Siglo Veintiuno Editores.

Wright, Gavin (1986) Old South, New South, New York: Basic Books. 
Table 1

Descriptive Statistics

\begin{tabular}{|c|c|c|c|c|c|}
\hline & $\begin{array}{c}\begin{array}{c}\text { All } \\
\text { Municipalities }\end{array} \\
(1)\end{array}$ & $\begin{array}{l}\begin{array}{l}\text { Low Land } \\
\text { Inequality }\end{array} \\
(2)\end{array}$ & $\begin{array}{c}\text { High Land } \\
\text { Inequality }\end{array}$ & $\begin{array}{l}\begin{array}{l}\text { Low Political } \\
\text { Concentration }\end{array} \\
(4)\end{array}$ & $\begin{array}{l}\begin{array}{l}\text { High Political } \\
\text { Concentration }\end{array} \\
(5)\end{array}$ \\
\hline \multirow{2}{*}{ Land Gini } & 0.65 & 0.57 & 0.73 & 0.66 & 0.65 \\
\hline & $(0.10)$ & $(0.06)$ & $(0.05)$ & $(0.09)$ & $(0.10)$ \\
\hline \multirow{2}{*}{ Overall Land Gini } & 0.86 & 0.83 & 0.90 & 0.86 & 0.87 \\
\hline & 0.07 & 0.07 & 0.05 & 0.07 & 0.07 \\
\hline \multirow{2}{*}{ Contemporary Land Gini } & 0.67 & 0.63 & 0.73 & 0.69 & 0.66 \\
\hline & $(0.09)$ & $(0.07)$ & $(0.08)$ & $(0.09)$ & $(0.09)$ \\
\hline \multirow{2}{*}{ Political Concentration Index } & -0.56 & -0.53 & -0.57 & -0.64 & -0.48 \\
\hline & $(0.10)$ & $(0.08)$ & $(0.10)$ & $(0.06)$ & $(0.06)$ \\
\hline \multirow{2}{*}{ Overlap } & 0.07 & 0.07 & 0.06 & 0.05 & 0.08 \\
\hline & $(0.04)$ & $(0.04)$ & $(0.04)$ & $(0.03)$ & $(0.04)$ \\
\hline \multirow{2}{*}{$\begin{array}{c}\text { Secondary School } \\
\text { Enrollment }\end{array}$} & 0.58 & 0.52 & 0.65 & 0.60 & 0.56 \\
\hline & $(0.11)$ & $(0.09)$ & $(0.09)$ & $(0.11)$ & $(0.10)$ \\
\hline \multirow{2}{*}{ Primary School Enrollment } & 0.83 & 0.83 & 0.86 & 0.84 & 0.84 \\
\hline & $(0.06)$ & $(0.05)$ & $(0.07)$ & $(0.08)$ & $(0.05)$ \\
\hline \multirow{2}{*}{ Urbanization (1993) } & 0.31 & 0.22 & 0.41 & 0.35 & 0.26 \\
\hline & $(0.23)$ & $(0.13)$ & $(0.28)$ & $(0.26)$ & $(0.20)$ \\
\hline \multirow{2}{*}{ Unsatisfied Basic Needs } & 0.40 & 0.44 & 0.33 & 0.37 & 0.42 \\
\hline & $(0.14)$ & $(0.13)$ & $(0.11)$ & $(0.14)$ & $(0.14)$ \\
\hline \multirow{2}{*}{ Literacy Rate } & 0.40 & 0.40 & 0.41 & 0.42 & 0.38 \\
\hline & $(0.12)$ & $(0.12)$ & $(0.10)$ & $(0.13)$ & $(0.10)$ \\
\hline \multirow{2}{*}{ Urbanization (1937) } & 0.17 & 0.12 & 0.20 & 0.20 & 0.14 \\
\hline & $(0.18)$ & $(0.10)$ & $(0.18)$ & $(0.22)$ & $(0.13)$ \\
\hline \multirow{2}{*}{$\begin{array}{l}\text { Share of Buildings without } \\
\text { Access to Public Services }\end{array}$} & 0.91 & 0.95 & 0.88 & 0.88 & 0.94 \\
\hline & $(0.12)$ & $(0.07)$ & $(0.13)$ & $(0.16)$ & $(0.08)$ \\
\hline \multirow{2}{*}{ Distance to Bogota } & 88.23 & 93.49 & 77.96 & 85.84 & 90.53 \\
\hline & $(45.00)$ & $(38.74)$ & $(48.35)$ & (44.28) & $(46.01)$ \\
\hline
\end{tabular}

Values are averages with standard deviations in parentheses. Land Gini is the average land value gini coefficient for 1879 and 1890 constructed from the catastros. Overall Land Gini is the average land value gini coefficient for 1879 and 1890 constructed from the catastros taking into account landless families (see text for details) Political Concentration Index measured as the negative of the number of different individuals in power between 1875 and 1895 over number of mayor appointments for which data is available. Overlap is measured as fraction of rich landowners and politicians that are both landowners and politicians (average for 1879 and 1890). Contemporary Land Gini corresponds to gini coefficient of land value for 2002 constructed from IGAC catastros. Secondary School Enrollment is constructed from the 1993 Census as fraction of kids between 12 and 17 years old attending school. Primary School Enrollment also constructed from the 1993 Census as fraction of kids between 7 and 11 years old attending school. Unsatisfied Basic Needs constructed from the 1993 Census as fraction of households with unfulfilled basic needs (see text for details).

Urbanization figures constructed from the corresponding year censuses as fraction of total population leaving in urban areas. Literacy Rate constructed from the 1937 Census as number of literate individuals over total population. Fraction of Buildings without Access to Public Services also constructed from 1937 Census as number of buildings without access to electricity, water and sewage. Distance to Bogota is measured in kms. Column 1 reports figures for all municipalities. Column 2 reports figure for the 49 municipalities with land gini below its median value while column 3 reports figures for the 49 municipalities with land gini above its median value. Column 4 reports figures for the 56 municipalities with Political Concentration Index below its median value and column 5 reports figures for the 56 municipalities with Political Concentration Index above its median value. 
Table 2

Correlation Matrix

\begin{tabular}{|c|c|c|c|c|c|c|c|c|}
\hline & Land Gini & $\begin{array}{l}\text { Overall Land } \\
\text { Gini }\end{array}$ & $\begin{array}{c}\text { Contemporary Land } \\
\text { Gini }\end{array}$ & $\begin{array}{c}\text { Political } \\
\text { Concentration } \\
\text { Index }\end{array}$ & Overlap & $\begin{array}{l}\text { Secondary } \\
\text { School } \\
\text { Enrollment }\end{array}$ & $\begin{array}{l}\text { Urbanization } \\
\text { (1993) }\end{array}$ & $\begin{array}{l}\text { Unsatisfied } \\
\text { Basic } \\
\text { Needs }\end{array}$ \\
\hline Land Gini & 1.00 & & & & & & & \\
\hline Overall Land Gini & 0.48 & 1.00 & & & & & & \\
\hline Contemporary Land Gini & 0.60 & 0.23 & 1.00 & & & & & \\
\hline Political Concentration Index & -0.25 & -0.05 & -0.26 & 1.00 & & & & \\
\hline Overlap & -0.08 & -0.05 & -0.04 & 0.43 & 1.00 & & & \\
\hline Secondary School Enrollment & 0.54 & 0.16 & 0.56 & -0.30 & -0.09 & 1.00 & & \\
\hline Urbanization (1993) & 0.47 & 0.11 & 0.59 & -0.30 & -0.10 & 0.64 & 1.00 & \\
\hline Unsatisfied Basic Needs & -0.56 & 0.09 & -0.49 & 0.37 & -0.03 & -0.67 & -0.47 & 1.00 \\
\hline
\end{tabular}

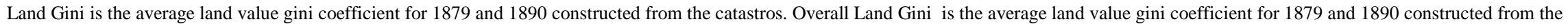

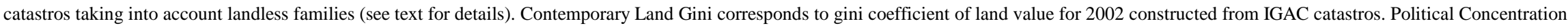

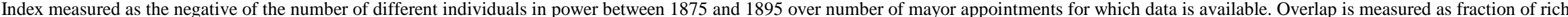

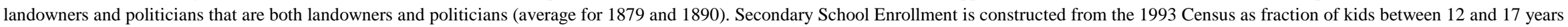

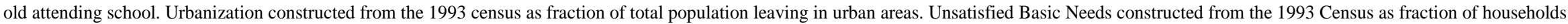
with unfulfilled basic needs (see text for details). 
Table 3

Land Inequality in U.S. States (1860)

\begin{tabular}{lccc}
\hline \hline State & Land Gini & No. Observations & Average Land Value \\
Panel A. Northern States & & & \\
Connecticut & 0.34 & 259 & 3,421 \\
Illinois & 0.50 & 1,563 & 2,659 \\
Indiana & 0.47 & 5,020 & 2,534 \\
lowa & 0.48 & 825 & 2,066 \\
Kansas & 0.41 & 623 & 1,702 \\
Maryland & 0.49 & 534 & 2,097 \\
Michigan & 0.55 & 1,516 & 1,544 \\
Minnesota & 0.55 & 379 & 983 \\
Missouri & 0.52 & 1,180 & 1,745 \\
New Hampshire & 0.35 & 807 & 1,860 \\
New Jersey & 0.35 & 362 & 5,274 \\
New York & 0.42 & 4,043 & 3,888 \\
Ohio & 0.38 & 851 & 3,381 \\
Pennsylvania & 0.47 & 2,465 & 3,722 \\
Vermont & 0.43 & 147 & 3,327 \\
Wisconsin & 0.44 & 544 & 1,748 \\
\hline Total Northern States & 0.47 & 20,821 & 2,820 \\
\hline \hline Panel B. Southern States & & & \\
Alabama & 0.73 & 1,005 & 3,223 \\
Arkansas & 0.70 & 434 & 3,048 \\
Florida & 0.60 & 65 & 2,162 \\
Georgia & 0.63 & 818 & 3,459 \\
Louisiana & 0.83 & 225 & 18,197 \\
Mississippi & 0.69 & 707 & 4,491 \\
North Carolina & 0.60 & 391 & 2,548 \\
South Carolina & 0.63 & 524 & 4,293 \\
Tennessee & 0.75 & 465 & 3,340 \\
Texas & 0.70 & 551 & 4,555 \\
Virginia & 0.71 & 4,055 & 3,333 \\
\hline Total Southern States & 0.72 & 25,876 & \\
\hline \hline Total U.S. States & 0.58 & $c 05$ & \\
\hline The & & & \\
\hline & & & \\
\hline
\end{tabular}

The land ginis for the US south and north were constructed from the complete 'Gallman-Parker and Bateman-Foust samples, respectively, from the micro data of 1860 US 'census. 
Table 4

OLS Regressions for Long Term Oucomes

\begin{tabular}{|c|c|c|c|c|c|c|c|c|c|c|}
\hline & (1) & (2) & (3) & (4) & (5) & (6) & $\overline{(7)}$ & (8) & (9) & (10) \\
\hline Panel A & \multicolumn{10}{|c|}{ Dependent Variable: Secondary School Enrollment } \\
\hline Land Gini & $\begin{array}{c}0.61 \\
(0.09)\end{array}$ & $\begin{array}{c}0.48 \\
(0.10)\end{array}$ & & & & & $\begin{array}{c}0.44 \\
(0.09)\end{array}$ & $\begin{array}{c}0.44 \\
(0.09)\end{array}$ & $\begin{array}{c}0.28 \\
(0.11)\end{array}$ & $\begin{array}{c}0.16 \\
(0.10)\end{array}$ \\
\hline Political Concentration Index & & & $\begin{array}{l}-0.36 \\
(0.11)\end{array}$ & $\begin{array}{l}-0.35 \\
(0.10)\end{array}$ & & & $\begin{array}{l}-0.27 \\
(0.10)\end{array}$ & $\begin{array}{l}-0.27 \\
(0.11)\end{array}$ & $\begin{array}{l}-0.22 \\
(0.11)\end{array}$ & $\begin{array}{l}-0.22 \\
(0.11)\end{array}$ \\
\hline Overlap & & & & & $\begin{array}{l}-0.27 \\
(0.29)\end{array}$ & $\begin{array}{l}-0.43 \\
(0.24)\end{array}$ & & $\begin{array}{l}-0.01 \\
(0.23)\end{array}$ & $\begin{array}{l}-0.07 \\
(0.19)\end{array}$ & $\begin{array}{l}-0.13 \\
(0.19)\end{array}$ \\
\hline Contemporary Land Gini & & & & & & & & & $\begin{array}{c}0.38 \\
(0.13)\end{array}$ & $\begin{array}{c}0.37 \\
(0.11)\end{array}$ \\
\hline Geographic Controls & No & Yes & No & Yes & No & Yes & Yes & Yes & Yes & Extended \\
\hline Observations & 92 & 92 & 94 & 93 & 93 & 93 & 92 & 92 & 92 & 92 \\
\hline R-squared & 0.30 & 0.45 & 0.09 & 0.37 & 0.01 & 0.32 & 0.50 & 0.50 & 0.54 & 0.61 \\
\hline$\overline{\text { Panel B }}$ & \multicolumn{10}{|c|}{ "Dependent Variable: Primary School Enrollment } \\
\hline Land Gini & $\begin{array}{c}0.19 \\
(0.06)\end{array}$ & $\begin{array}{c}0.11 \\
(0.05)\end{array}$ & & & & & $\begin{array}{c}0.10 \\
(0.05)\end{array}$ & $\begin{array}{c}0.10 \\
(0.05)\end{array}$ & $\begin{array}{c}0.12 \\
(0.06)\end{array}$ & $\begin{array}{c}0.05 \\
(0.05)\end{array}$ \\
\hline Political Concentration Index & & & $\begin{array}{c}-0.08 \\
(0.07)\end{array}$ & $\begin{array}{l}-0.09 \\
(0.05)\end{array}$ & & & $\begin{array}{c}-0.07 \\
(0.05)\end{array}$ & $\begin{array}{l}-0.11 \\
(0.06)\end{array}$ & $\begin{array}{l}-0.11 \\
(0.06)\end{array}$ & $\begin{array}{l}-0.08 \\
(0.06)\end{array}$ \\
\hline Overlap & & & & & $\begin{array}{c}0.04 \\
(0.16)\end{array}$ & $\begin{array}{c}0.02 \\
(0.12)\end{array}$ & & $\begin{array}{c}0.17 \\
(0.14)\end{array}$ & $\begin{array}{c}0.18 \\
(0.14)\end{array}$ & $\begin{array}{c}0.12 \\
(0.13)\end{array}$ \\
\hline Contemporary Land Gini & & & & & & & & & $\begin{array}{l}-0.04 \\
(0.07)\end{array}$ & $\begin{array}{c}0.00 \\
(0.06)\end{array}$ \\
\hline Geographic Controls & No & Yes & No & Yes & No & Yes & Yes & Yes & Yes & Extended \\
\hline Observations & 92 & 92 & 94 & 93 & 93 & 93 & 92 & 92 & 92 & 92 \\
\hline R-squared & 0.09 & 0.52 & 0.01 & 0.51 & 0.00 & 0.49 & 0.53 & 0.54 & 0.54 & 0.60 \\
\hline
\end{tabular}

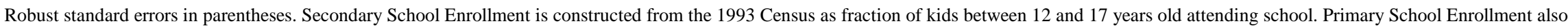

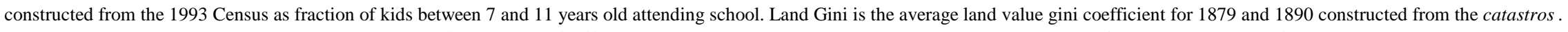

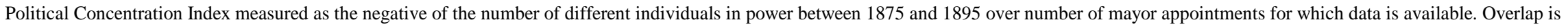

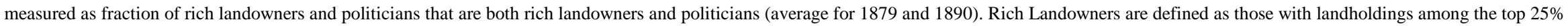

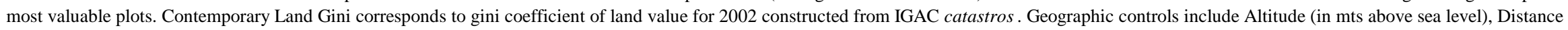

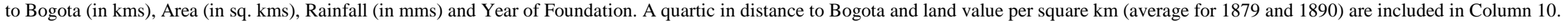


Table 5

OLS Regressions for Long Term Oucomes

\begin{tabular}{|c|c|c|c|c|c|c|c|c|c|c|}
\hline & (1) & $(2)$ & (3) & (4) & (5) & (6) & (7) & (8) & (9) & $(10)$ \\
\hline Panel A & \multicolumn{10}{|c|}{ Dependent Variable: Urbanization in 1993} \\
\hline Land Gini & $\begin{array}{c}1.11 \\
(0.23)\end{array}$ & $\begin{array}{c}0.79 \\
(0.21)\end{array}$ & & & & & $\begin{array}{c}0.71 \\
(0.21)\end{array}$ & $\begin{array}{c}0.71 \\
(0.20)\end{array}$ & $\begin{array}{c}0.21 \\
(0.23)\end{array}$ & $\begin{array}{c}0.06 \\
(0.23)\end{array}$ \\
\hline Political Concentration Index & & & $\begin{array}{l}-0.77 \\
(0.26)\end{array}$ & $\begin{array}{l}-0.57 \\
(0.27)\end{array}$ & & & $\begin{array}{l}-0.44 \\
(0.29)\end{array}$ & $\begin{array}{c}-0.33 \\
(0.32)\end{array}$ & $\begin{array}{c}-0.15 \\
(0.28)\end{array}$ & $\begin{array}{c}-0.26 \\
(0.27)\end{array}$ \\
\hline Overlap & & & & & $\begin{array}{c}-0.65 \\
(0.66)\end{array}$ & $\begin{array}{c}-1.07 \\
(0.55)\end{array}$ & & $\begin{array}{c}-0.51 \\
(0.65)\end{array}$ & $\begin{array}{c}-0.73 \\
(0.56)\end{array}$ & $\begin{array}{c}-0.32 \\
(0.46)\end{array}$ \\
\hline Contemporary Land Gini & & & & & & & & & $\begin{array}{c}1.23 \\
(0.28)\end{array}$ & $\begin{array}{c}0.97 \\
(0.28)\end{array}$ \\
\hline Geographic Controls & No & Yes & No & Yes & No & Yes & Yes & Yes & Yes & Extended \\
\hline Observations & 92 & 92 & 94 & 93 & 93 & 93 & 92 & 92 & 92 & 92 \\
\hline R-squared & 0.22 & 0.36 & 0.09 & 0.31 & 0.01 & 0.30 & 0.38 & 0.39 & 0.50 & 0.6 \\
\hline Panel B & \multicolumn{10}{|c|}{ Dependent Variable: Unsatisfied Basic Needs } \\
\hline Land Gini & $\begin{array}{l}-0.72 \\
(0.12)\end{array}$ & $\begin{array}{l}-0.49 \\
(0.12)\end{array}$ & & & & & $\begin{array}{l}-0.44 \\
(0.11)\end{array}$ & $\begin{array}{c}-0.44 \\
(0.11)\end{array}$ & $\begin{array}{c}-0.35 \\
(0.13)\end{array}$ & $\begin{array}{l}-0.21 \\
(0.11)\end{array}$ \\
\hline Political Concentration Index & & & $\begin{array}{c}0.51 \\
(0.12)\end{array}$ & $\begin{array}{c}0.36 \\
(0.11)\end{array}$ & & & $\begin{array}{c}0.28 \\
(0.11)\end{array}$ & $\begin{array}{c}0.41 \\
(0.12)\end{array}$ & $\begin{array}{c}0.38 \\
(0.12)\end{array}$ & $\begin{array}{c}0.33 \\
(0.12)\end{array}$ \\
\hline Overlap & & & & & $\begin{array}{c}-0.11 \\
(0.35)\end{array}$ & $\begin{array}{c}-0.03 \\
(0.26)\end{array}$ & & $\begin{array}{c}-0.62 \\
(0.25)\end{array}$ & $\begin{array}{c}-0.58 \\
(0.23)\end{array}$ & $\begin{array}{c}-0.6 \\
(0.24)\end{array}$ \\
\hline Contemporary Land Gini & & & & & & & & & $\begin{array}{c}-0.23 \\
(0.13)\end{array}$ & $\begin{array}{l}-0.33 \\
(0.14)\end{array}$ \\
\hline Geographic Controls & No & Yes & No & Yes & No & Yes & Yes & Yes & Yes & Extended \\
\hline Observations & 92 & 92 & 94 & 93 & 93 & 93 & 92 & 92 & 92 & 92 \\
\hline R-squared & 0.31 & 0.57 & 0.14 & 0.51 & 0.00 & 0.45 & 0.61 & 0.63 & 0.64 & 0.69 \\
\hline
\end{tabular}

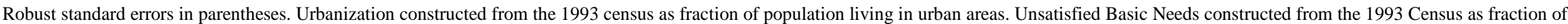

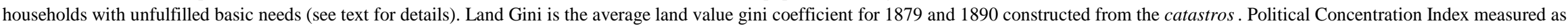

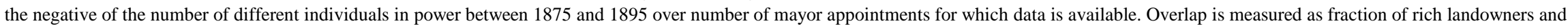

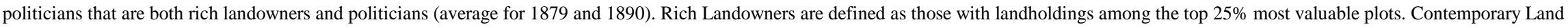

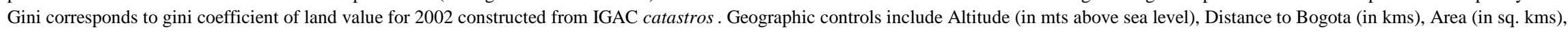
Rainfall (in mms) and Year of Foundation. A quartic in distance to Bogota and land value per square km (average for 1879 and 1890 ) are included in Column 10. 
Table 6

OLS Regressions for Medium Term Oucomes

\begin{tabular}{|c|c|c|c|c|c|c|c|c|c|}
\hline & (1) & (2) & (3) & (4) & (5) & (6) & (7) & (8) & (9) \\
\hline Panel A & \multicolumn{9}{|c|}{ Dependent Variable: Literacy Rate in 1937} \\
\hline \multirow[t]{2}{*}{ Land Gini } & 0.27 & 0.09 & & & & & 0.04 & 0.04 & 0.00 \\
\hline & $(0.11)$ & $(0.11)$ & & & & & $(0.11)$ & $(0.11)$ & $(0.13)$ \\
\hline \multirow[t]{2}{*}{ Political Concentration Index } & & & -0.31 & -0.27 & & & -0.27 & -0.30 & -0.29 \\
\hline & & & $(0.11)$ & $(0.12)$ & & & $(0.12)$ & $(0.12)$ & $(0.14)$ \\
\hline Overlap & & & & & -0.16 & -0.19 & & 0.17 & 0.21 \\
\hline Geographic Controls & No & Yes & No & Yes & No & Yes & Yes & Yes & Extended \\
\hline Observations & 97 & 91 & 99 & 92 & 98 & 92 & 91 & 91 & 91 \\
\hline R-squared & 0.05 & 0.26 & 0.06 & 0.30 & 0.00 & 0.26 & 0.30 & 0.30 & 0.31 \\
\hline Panel B & \multicolumn{9}{|c|}{ Dependent Variable: Urbanization in 1937} \\
\hline \multirow[t]{2}{*}{ Land Gini } & 0.42 & 0.31 & & & & & 0.24 & 0.24 & -0.02 \\
\hline & $(0.13)$ & $(0.13)$ & & & & & $(0.12)$ & $(0.12)$ & $(0.15)$ \\
\hline & & & $(0.20)$ & $(0.24)$ & & & $(0.25)$ & $(0.27)$ & $(0.31)$ \\
\hline \multirow[t]{2}{*}{ Overlap } & & & & & -0.67 & -0.73 & & -0.24 & 0.16 \\
\hline & & & & & $(0.37)$ & $(0.40)$ & & $(0.39)$ & $(0.36)$ \\
\hline Geographic Controls & No & Yes & No & Yes & No & Yes & Yes & Yes & Extended \\
\hline Observations & 98 & 92 & 100 & 93 & 99 & 93 & 92 & 92 & 92 \\
\hline$\underline{\text { R-squared }}$ & 0.08 & 0.14 & 0.06 & 0.18 & 0.03 & 0.13 & 0.20 & 0.20 & 0.35 \\
\hline
\end{tabular}

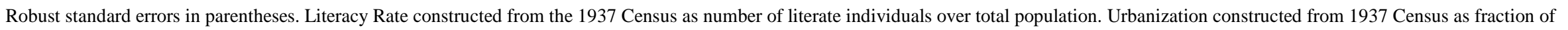

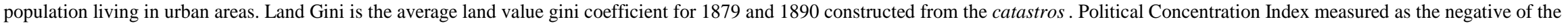

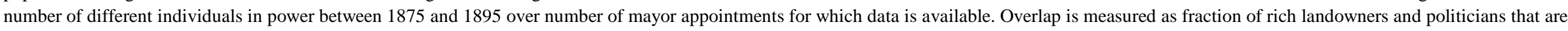

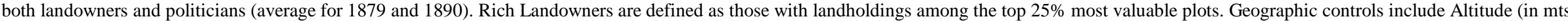

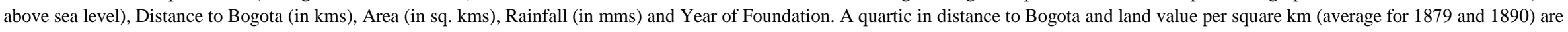
included in Column 9. 
Table 7

OLS Regressions for Medium Term Oucomes

\begin{tabular}{|c|c|c|c|c|c|c|c|c|c|}
\hline & $(1)$ & (2) & (3) & (4) & (5) & (6) & (7) & (8) & (9) \\
\hline Panel A & \multicolumn{9}{|c|}{ Dependent Variable: Fraction of Buildings without Access to Public Services } \\
\hline Land Gini & $\begin{array}{c}-0.41 \\
(0.09)\end{array}$ & $\begin{array}{l}-0.23 \\
(0.08)\end{array}$ & & & & & $\begin{array}{l}-0.17 \\
(0.07)\end{array}$ & $\begin{array}{c}-0.16 \\
(0.07)\end{array}$ & $\begin{array}{l}-0.03 \\
(0.08)\end{array}$ \\
\hline Political Concentration Index & & & $\begin{array}{c}0.46 \\
(0.14)\end{array}$ & $\begin{array}{c}0.41 \\
(0.17)\end{array}$ & & & $\begin{array}{c}0.38 \\
(0.17)\end{array}$ & $\begin{array}{c}0.35 \\
(0.20)\end{array}$ & $\begin{array}{c}0.35 \\
(0.23)\end{array}$ \\
\hline Overlap & & & & & $\begin{array}{c}0.55 \\
(0.26)\end{array}$ & $\begin{array}{c}0.61 \\
(0.22)\end{array}$ & & $\begin{array}{c}0.17 \\
(0.23)\end{array}$ & $\begin{array}{l}-0.07 \\
(0.21)\end{array}$ \\
\hline Geographic Controls & No & Yes & No & Yes & No & Yes & Yes & Yes & Extended \\
\hline Observations & 97 & 91 & 98 & 92 & 98 & 92 & 91 & 91 & 91 \\
\hline R-squared & 0.13 & 0.25 & 0.16 & 0.33 & 0.03 & 0.26 & 0.36 & 0.36 & 0.44 \\
\hline
\end{tabular}

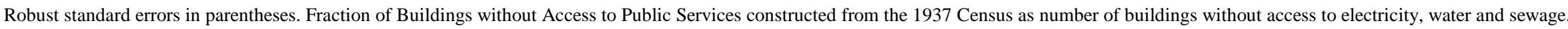

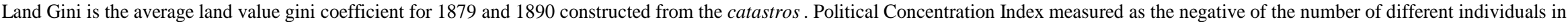

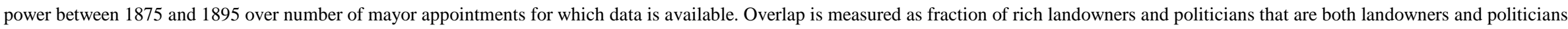

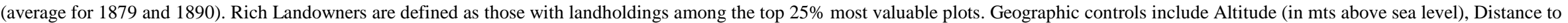

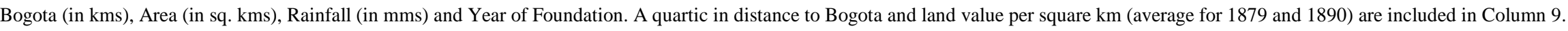


Table 8

OLS Regressions for Long and Medium Term Oucomes

\begin{tabular}{|c|c|c|c|c|c|c|c|c|}
\hline & (1) & (2) & (3) & (4) & (5) & (6) & (7) & (8) \\
\hline \multirow[t]{2}{*}{ Panel A: Long Term Outcomes } & \multicolumn{8}{|c|}{ Dependent Variable: } \\
\hline & \multicolumn{2}{|c|}{$\begin{array}{l}\text { Secondary School } \\
\text { Enrollment }\end{array}$} & \multicolumn{2}{|c|}{$\begin{array}{c}\text { Primary School } \\
\text { Enrollment }\end{array}$} & \multicolumn{2}{|c|}{$\begin{array}{l}\text { Urbanization } \\
\text { (1993) }\end{array}$} & \multicolumn{2}{|c|}{$\begin{array}{l}\text { Unsatisfied Basic } \\
\text { Needs }\end{array}$} \\
\hline Land Gini & $\begin{array}{c}0.30 \\
(0.13)\end{array}$ & $\begin{array}{c}0.14 \\
(0.12)\end{array}$ & $\begin{array}{c}0.20 \\
(0.07)\end{array}$ & $\begin{array}{c}0.13 \\
(0.07)\end{array}$ & $\begin{array}{c}0.26 \\
(0.28)\end{array}$ & $\begin{array}{c}0.07 \\
(0.31)\end{array}$ & $\begin{array}{l}-0.50 \\
(0.16)\end{array}$ & $\begin{array}{l}-0.34 \\
(0.16)\end{array}$ \\
\hline Overall Land Gini & $\begin{array}{l}-0.03 \\
(0.13)\end{array}$ & $\begin{array}{c}0.04 \\
(0.15)\end{array}$ & $\begin{array}{l}-0.19 \\
(0.08)\end{array}$ & $\begin{array}{l}-0.15 \\
(0.07)\end{array}$ & $\begin{array}{l}-0.07 \\
(0.28)\end{array}$ & $\begin{array}{l}-0.02 \\
(0.29)\end{array}$ & $\begin{array}{c}0.34 \\
(0.17)\end{array}$ & $\begin{array}{c}0.23 \\
(0.17)\end{array}$ \\
\hline Political Concentration Index & $\begin{array}{l}-0.23 \\
(0.09)\end{array}$ & $\begin{array}{l}-0.24 \\
(0.10)\end{array}$ & $\begin{array}{l}-0.07 \\
(0.05)\end{array}$ & $\begin{array}{l}-0.06 \\
(0.05)\end{array}$ & $\begin{array}{l}-0.31 \\
(0.25)\end{array}$ & $\begin{array}{l}-0.32 \\
(0.26)\end{array}$ & $\begin{array}{c}0.25 \\
(0.10)\end{array}$ & $\begin{array}{c}0.22 \\
(0.11)\end{array}$ \\
\hline Contemporary Land Gini & $\begin{array}{c}0.37 \\
(0.13)\end{array}$ & $\begin{array}{c}0.37 \\
(0.11)\end{array}$ & $\begin{array}{l}-0.05 \\
(0.07)\end{array}$ & $\begin{array}{l}-0.02 \\
(0.06)\end{array}$ & $\begin{array}{c}1.19 \\
(0.29)\end{array}$ & $\begin{array}{c}0.95 \\
(0.27)\end{array}$ & $\begin{array}{l}-0.22 \\
(0.14)\end{array}$ & $\begin{array}{l}-0.33 \\
(0.14)\end{array}$ \\
\hline Geographic Controls & Yes & Extended & Yes & Extended & Yes & Extended & Yes & Extended \\
\hline Observations & 92 & 92 & 92 & 92 & 92 & 92 & 92 & 92 \\
\hline R-squared & 0.54 & 0.60 & 0.55 & 0.61 & 0.49 & 0.60 & 0.64 & 0.67 \\
\hline \multirow[t]{2}{*}{ Panel B: Medium Term Outcomes } & \multicolumn{8}{|c|}{ Dependent Variable: } \\
\hline & \multicolumn{4}{|c|}{$\begin{array}{l}\text { Urbanization } \\
\text { (1937) }\end{array}$} & \multicolumn{2}{|c|}{$\begin{array}{c}\text { Lack of Public } \\
\text { Services }\end{array}$} & & \\
\hline Land Gini & $\begin{array}{c}0.22 \\
(0.13)\end{array}$ & $\begin{array}{c}0.22 \\
(0.16)\end{array}$ & $\begin{array}{c}0.43 \\
(0.15)\end{array}$ & $\begin{array}{c}0.14 \\
(0.24)\end{array}$ & $\begin{array}{l}-0.28 \\
(0.08)\end{array}$ & $\begin{array}{c}-0.11 \\
(0.14)\end{array}$ & & \\
\hline Overall Land Gini & $\begin{array}{l}-0.41 \\
(0.17)\end{array}$ & $\begin{array}{l}-0.41 \\
(0.17)\end{array}$ & $\begin{array}{l}-0.43 \\
(0.21)\end{array}$ & $\begin{array}{l}-0.30 \\
(0.28)\end{array}$ & $\begin{array}{c}0.25 \\
(0.14)\end{array}$ & $\begin{array}{c}0.16 \\
(0.18)\end{array}$ & & \\
\hline Political Concentration Index & $\begin{array}{l}-0.26 \\
(0.12)\end{array}$ & $\begin{array}{l}-0.27 \\
(0.14)\end{array}$ & $\begin{array}{c}-0.41 \\
(0.24)\end{array}$ & $\begin{array}{l}-0.30 \\
(0.27)\end{array}$ & $\begin{array}{c}0.38 \\
(0.17)\end{array}$ & $\begin{array}{c}0.34 \\
(0.20)\end{array}$ & & \\
\hline Geographic Controls & Yes & Extended & Yes & Extended & Yes & Extended & & \\
\hline Observations & 91 & 91 & 92 & 92 & 91 & 91 & & \\
\hline R-squared & 0.34 & 0.34 & 0.22 & 0.36 & 0.38 & 0.45 & & \\
\hline
\end{tabular}

Robust standard errors in parentheses. Land Gini is the average land value gini coefficient for 1879 and 1890 constructed from the catastros . Overall Land Gini is the average land value gini coefficient for 1879 and 1890 constructed from the catastros taking into account landless families (see text for details). Political Concentration Index measured as the negative of the number of different individuals in power between 1875 and 1895 over number of mayor appointments for which data is available. Contemporary Land Gini corresponds to gini coefficient of land value for 2002 constructed from IGAC catastros. Secondary School Enrollment is constructed from the 1993 Census as fraction of kids between 12 and 17 years old attending school. Primary School Enrollment also constructed from the 1993 Census as fraction of kids between 7 and 11 years old attending school. Unsatisfied Basic Needs constructed from the 1993 Census as fraction of households with unfulfilled basic needs (see text for details).

Urbanization figures constructed from the corresponding year censuses as fraction of total population leaving in urban areas. Literacy Rate constructed from the 1937 Census as number of literate individuals over total population. Lack of Public Services is fraction of buildings without zccess to public services constructed from 1937 Census as number of buildings without access to electricity, water and sewage. Geographic controls include Altitude (in mts above sea level), Distance to Bogota (in kms), Area (in sq. kms), Rainfall (in mms) and Year of Foundation. Extended Geographic controls include the former plus a quartic in distance to Bogota and land value per square km (average for 1879 and 1890 ). 
Table 9

OLS and Quantile Regressions for \% Change in Land Value

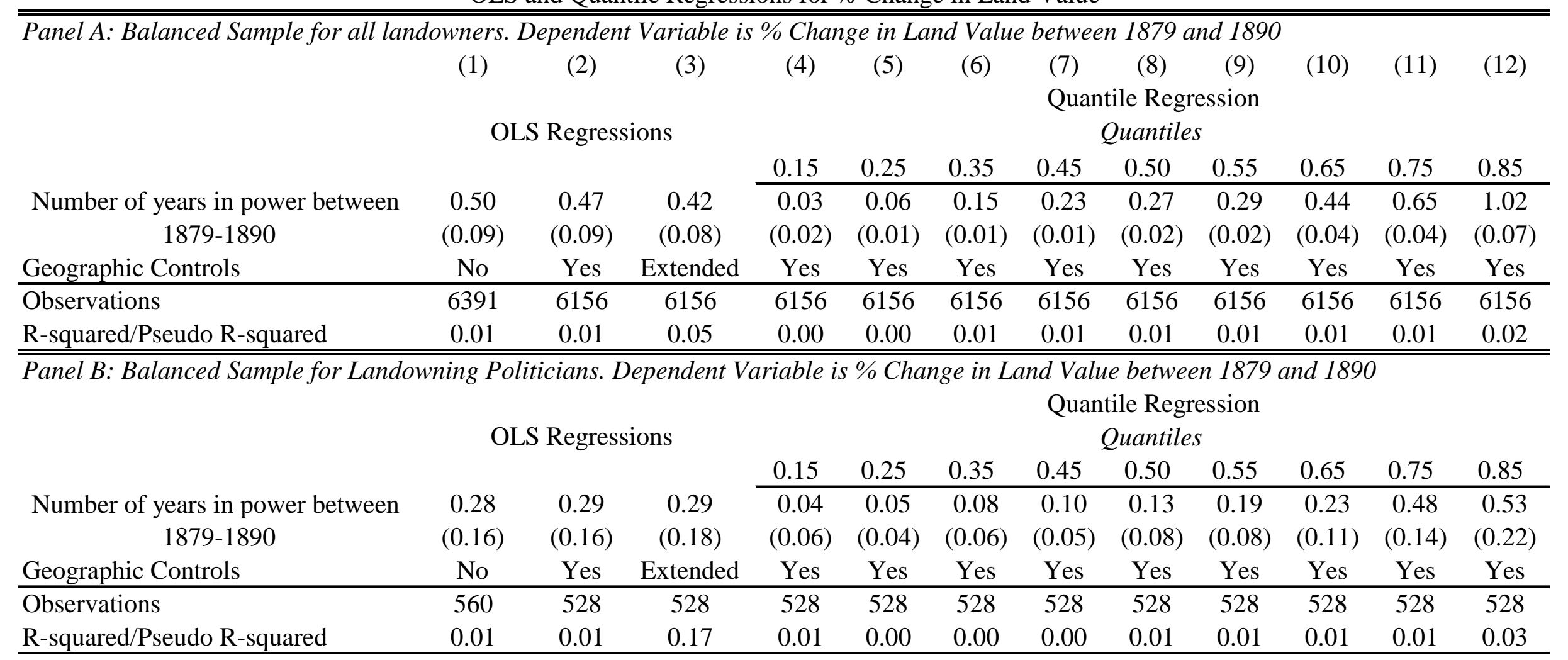

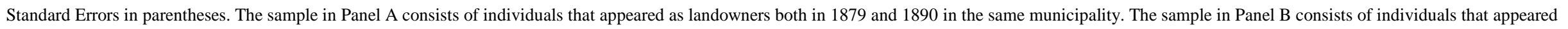

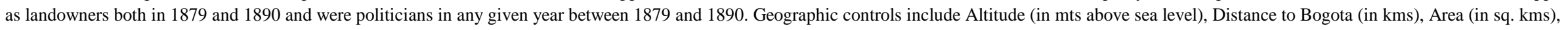

Rainfall (in mms) and Year of Foundation. Extended controls in column 3 include geographic controls and municipality dummies. 
Table 10

Conditional Probability Ratios

(a) Bogota

\begin{tabular}{|c|c|c|}
\hline Ratios & $r_{i t}^{o}$ & $p_{i t}^{o}$ \\
\hline$\frac{\operatorname{Pr}\left[r_{i t+1} \mid \bullet\right]}{\operatorname{Pr}\left[r_{i t+1} \mid l_{i t}\right]}$ & 13.58 & $\begin{array}{c}4.54 \\
(1.61)\end{array}$ \\
\hline$\frac{\operatorname{Pr}\left[p_{i t+1} \mid \bullet\right]}{\operatorname{Pr}\left[p_{i t+1} \mid l_{i t}\right]}$ & $1.96)$ \\
\hline
\end{tabular}

(c) Facatativa

\begin{tabular}{|c|c|c|}
\hline Ratios & $r_{i t}^{o}$ & $p_{i t}^{o}$ \\
\hline$\frac{\operatorname{Pr}\left[r_{i t+1} \mid \bullet\right]}{\operatorname{Pr}\left[r_{i t+1} \mid l_{i t}\right]}$ & 35.44 & 16.28 \\
$(4.43)$ & $(4.66)$ \\
\hline$\frac{\operatorname{Pr}\left[p_{i t+1} \mid \bullet\right]}{\operatorname{Pr}\left[p_{i t+1} \mid l_{i t}\right]}$ & $\begin{array}{c}21.34 \\
(11.78)\end{array}$ & $\begin{array}{c}50.02 \\
(32.16)\end{array}$ \\
\hline
\end{tabular}

(e) Guatativa

\begin{tabular}{|c|c|c|}
\hline Ratios & $r_{i t}^{o}$ & $p_{i t}^{o}$ \\
\hline$\frac{\operatorname{Pr}\left[r_{i t+1} \mid \bullet\right]}{\operatorname{Pr}\left[r_{i t+1} \mid l_{i t}\right]}$ & $\begin{array}{c}76.04 \\
(13.25)\end{array}$ & $\begin{array}{c}23.11 \\
(7.86)\end{array}$ \\
\hline$\frac{\operatorname{Pr}\left[p_{i t+1} \mid \bullet\right]}{\operatorname{Pr}\left[p_{i t+1} \mid l_{i t}\right]}$ & 20.28 & 41.71 \\
$(9.64)$ & $(22.75)$ \\
\hline
\end{tabular}

(g) Tequendama

\begin{tabular}{|c|c|c|}
\hline Ratios & $r_{i t}^{o}$ & $p_{i t}^{o}$ \\
\hline$\frac{\operatorname{Pr}\left[r_{i t+1} \mid \bullet\right]}{\operatorname{Pr}\left[r_{i t+1} \mid l_{i t}\right]}$ & 34.97 & 7.33 \\
\hline$\frac{\operatorname{Pr}\left[p_{i t+1} \mid \bullet 2\right.}{\operatorname{Pr}\left[p_{i t+1} \mid l_{i t}\right]}$ & 2.58 & $\mathbf{( 2 . 4 6 )}$ \\
\hline
\end{tabular}

(i) Zipaquira

\begin{tabular}{|c|c|c|}
\hline Ratios & $r_{i t}^{o}$ & $p_{i t}^{o}$ \\
\hline$\frac{\operatorname{Pr}\left[r_{i t+1} \mid \bullet\right]}{\operatorname{Pr}\left[r_{i t+1} \mid l_{i t}\right]}$ & 32.95 & 18.01 \\
\hline$\frac{\operatorname{Pr}\left[p_{i t+1} \mid \bullet\right]}{\operatorname{Pr}\left[p_{i t+1} \mid l_{i t}\right]}$ & $6.31)$ & $\mathbf{( 4 . 5 3 )}$ \\
\hline
\end{tabular}

(b) Choconta

\begin{tabular}{|c|c|c|}
\hline Ratios & $r_{i t}^{o}$ & $p_{i t}^{o}$ \\
\hline$\frac{\operatorname{Pr}\left[r_{i t+1} \mid \bullet\right]}{\operatorname{Pr}\left[r_{i t+1} \mid l_{i t}\right]}$ & $\begin{array}{c}80.70 \\
(15.98)\end{array}$ & $\begin{array}{c}22.94 \\
(10.52)\end{array}$ \\
\hline$\frac{\operatorname{Pr}\left[p_{i t+1} \mid \bullet\right]}{\operatorname{Pr}\left[p_{i t+1} \mid l_{i t}\right]}$ & $\begin{array}{c}14.74 \\
(7.19)\end{array}$ & $\begin{array}{c}33.52 \\
(18.87)\end{array}$ \\
\hline
\end{tabular}

(d) Guaduas

\begin{tabular}{|c|c|c|}
\hline Ratios & $r_{i t}^{o}$ & $p_{i t}^{o}$ \\
\hline$\frac{\operatorname{Pr}\left[r_{i t+1} \mid \bullet\right]}{\operatorname{Pr}\left[r_{i t+1} \mid l_{i t}\right]}$ & $\begin{array}{c}71.33 \\
(11.37)\end{array}$ & $\begin{array}{c}23.77 \\
(6.68)\end{array}$ \\
\hline$\frac{\operatorname{Pr}\left[p_{i t+1} \mid \bullet\right]}{\operatorname{Pr}\left[p_{i t+1} \mid l_{i t}\right]}$ & $\begin{array}{c}9.38 \\
(3.52)\end{array}$ & $\begin{array}{c}40.43 \\
(12.58)\end{array}$ \\
\hline
\end{tabular}

(f) Oriente

\begin{tabular}{|c|c|c|}
\hline Ratios & $r_{i t}^{o}$ & $p_{i t}^{o}$ \\
\hline$\frac{\operatorname{Pr}\left[r_{i t+1} \mid \bullet\right]}{\operatorname{Pr}\left[r_{i t+1} \mid l_{i t}\right]}$ & 45.25 & 17.05 \\
$(8.47)$ & $(7.07)$ \\
\hline$\frac{\operatorname{Pr}\left[p_{i t+1} \mid \bullet\right]}{\operatorname{Pr}\left[p_{i t+1} \mid l_{i t}\right]}$ & 5.93 & 36.85 \\
$(2.61)$ & $(15.65)$ \\
\hline
\end{tabular}

(h) Ubate

\begin{tabular}{|c|c|c|}
\hline Ratios & $r_{i t}^{o}$ & $p_{i t}^{o}$ \\
\hline$\frac{\operatorname{Pr}\left[r_{i t+1} \mid \bullet\right]}{\operatorname{Pr}\left[r_{i t+1} \mid l_{i t}\right]}$ & 39.60 & 22.63 \\
$(6.13)$ & $(5.93)$ \\
\hline$\frac{\operatorname{Pr}\left[p_{i t+1} \mid \bullet\right]}{\operatorname{Pr}\left[p_{i t+1} \mid l_{i t}\right]}$ & 7.80 & 30.15 \\
$(3.62)$ & $(15.05)$ \\
\hline
\end{tabular}

(j) Cundinamarca

\begin{tabular}{|c|c|c|}
\hline Ratios & $r_{i t}^{o}$ & $p_{i t}^{o}$ \\
\hline$\frac{\operatorname{Pr}\left[r_{i t+1} \mid \bullet\right]}{\operatorname{Pr}\left[r_{i t+1} \mid l_{i t}\right]}$ & $\begin{array}{c}39.19 \\
(1.86)\end{array}$ & $\begin{array}{c}14.55 \\
(1.41)\end{array}$ \\
\hline$\frac{\operatorname{Pr}\left[p_{i t+1} \mid \bullet\right]}{\operatorname{Pr}\left[p_{i t+1} \mid l_{i t}\right]}$ & $\begin{array}{c}6.48 \\
(0.87)\end{array}$ & $\begin{array}{l}34.48 \\
(4.25)\end{array}$ \\
\hline
\end{tabular}


Figure1

Land Gini and School Enrollment in the U.S.

(1870)

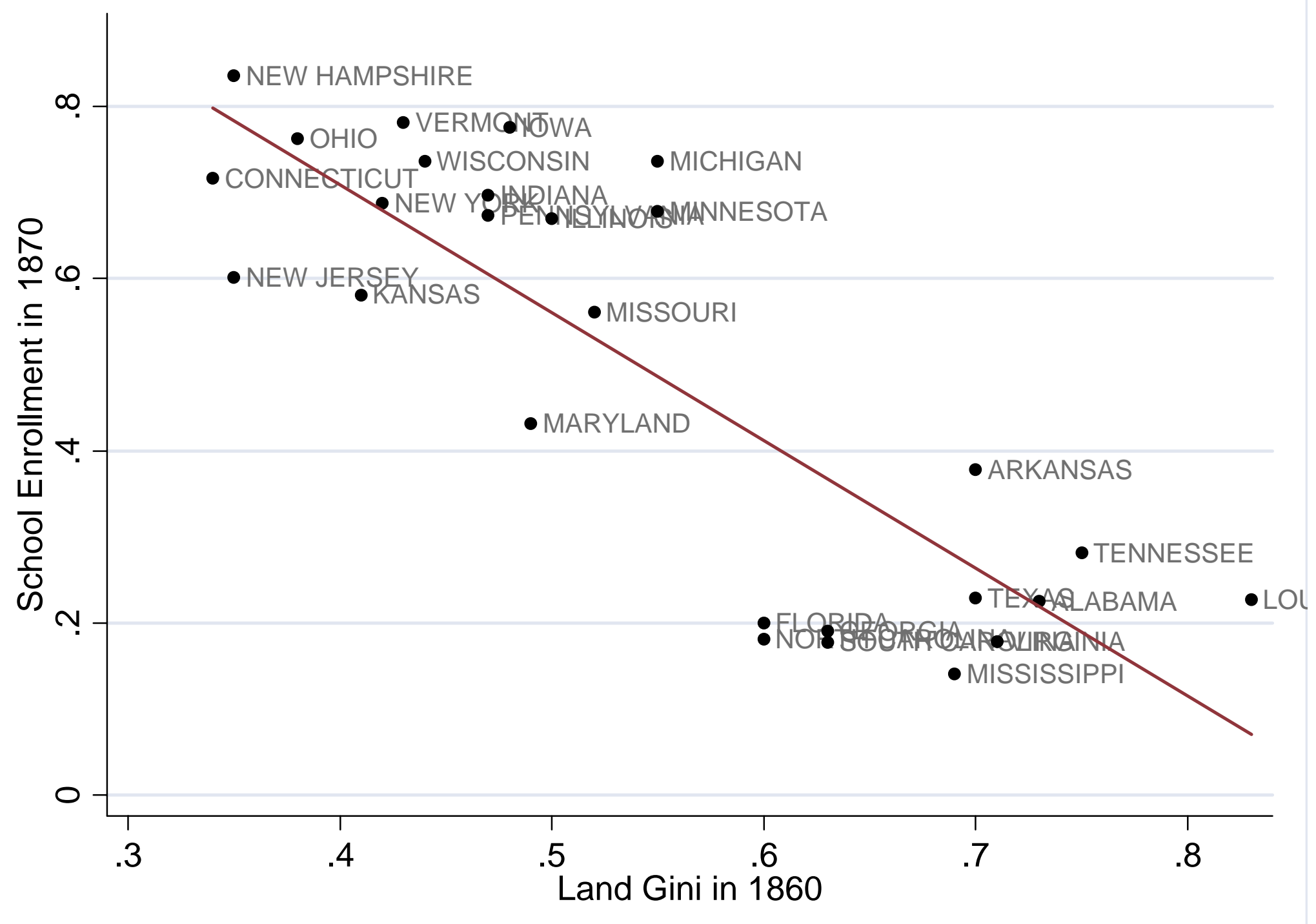

The land ginis for the US south and north were constructed from the complete Gallman-Parker and Bateman-Foust samples, respectively, from the micro data of 1860 US census. School enrollment constructed from the 1870 Census as Number of persons attending school over population between 5 and 18 years old. 
Figure2

Land Gini and School Enrollment in the U.S.

(1950)

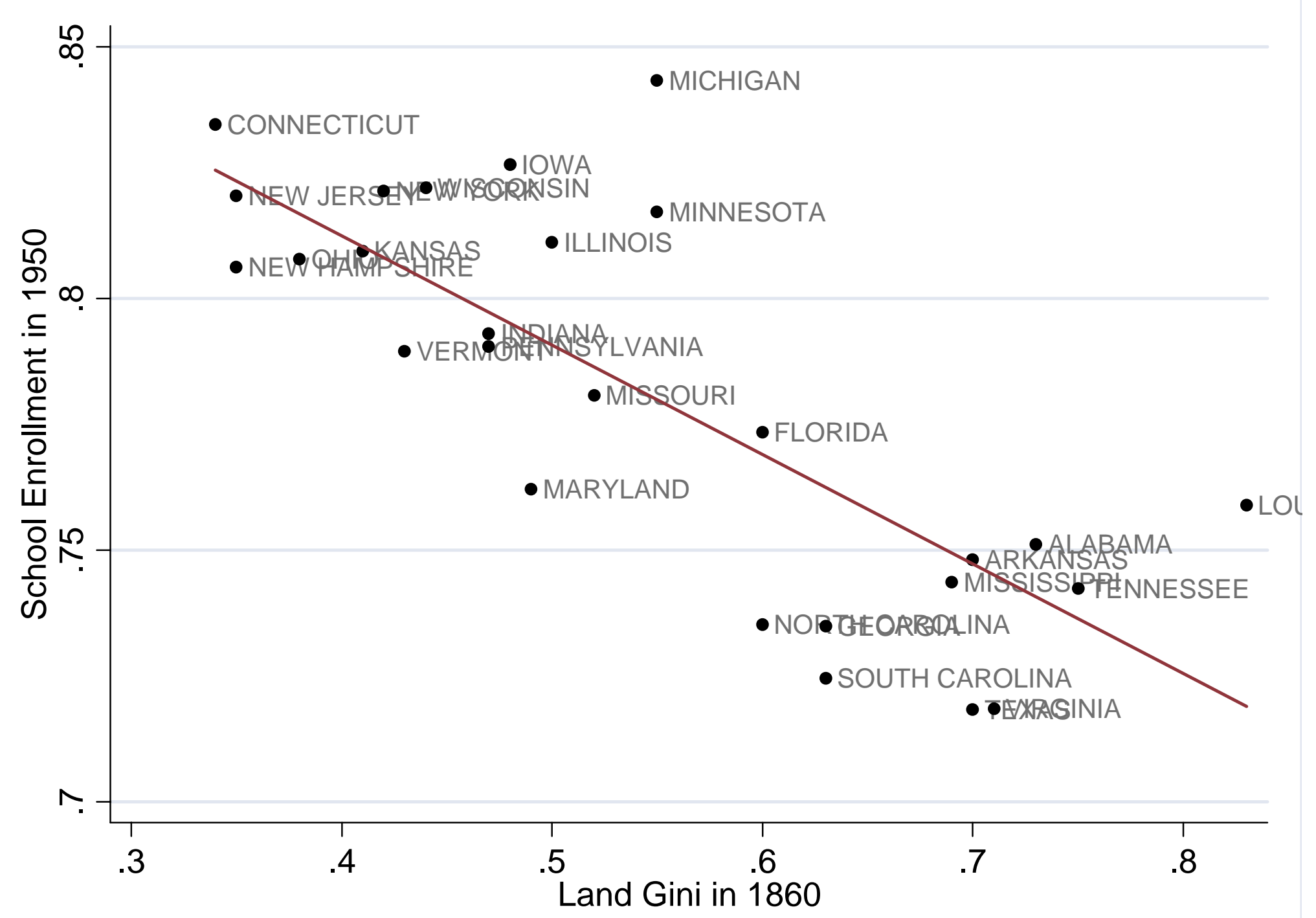

The land ginis for the US south and north were constructed from the complete Gallman-Parker and Bateman-Foust samples, respectively, from the micro data of 1860 US census. School enrollment constructed from the 1950 Census as Number of persons between 5 and 18 years old attending school over total population between 5 and 18 years old. 
Figure 3

Land Gini and Secondary School Enrollment in Cundinamarca

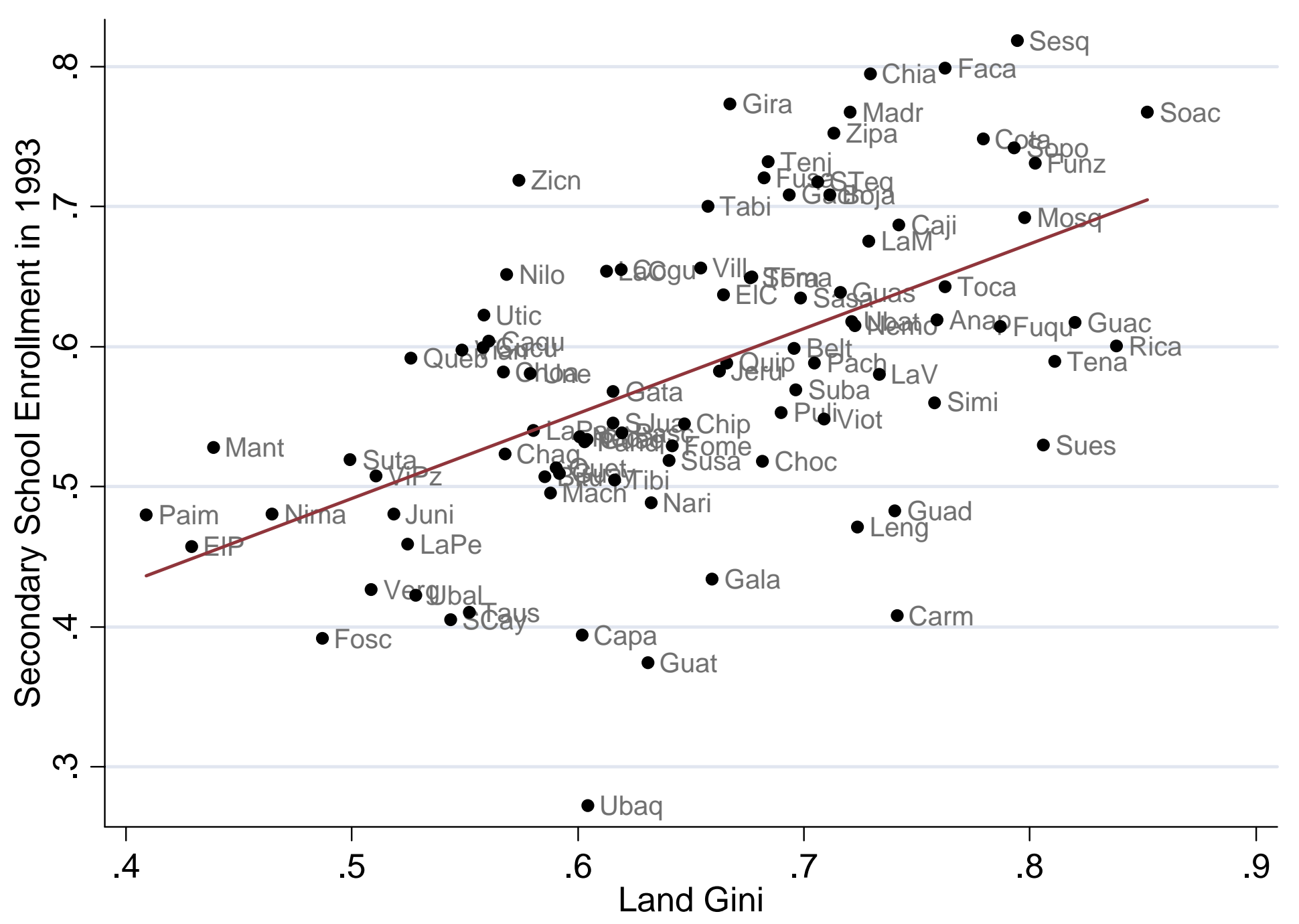

Land gini is the average gini coefficient for 1879 and 1890 constructed from the catastros. Secondary School Enrollment constructed from the 1993 Census as fraction of kids between 12 and 18 years old attending school. 
Figure 4

Political Concentration and Secondary School Enrollment in Cundinamarca

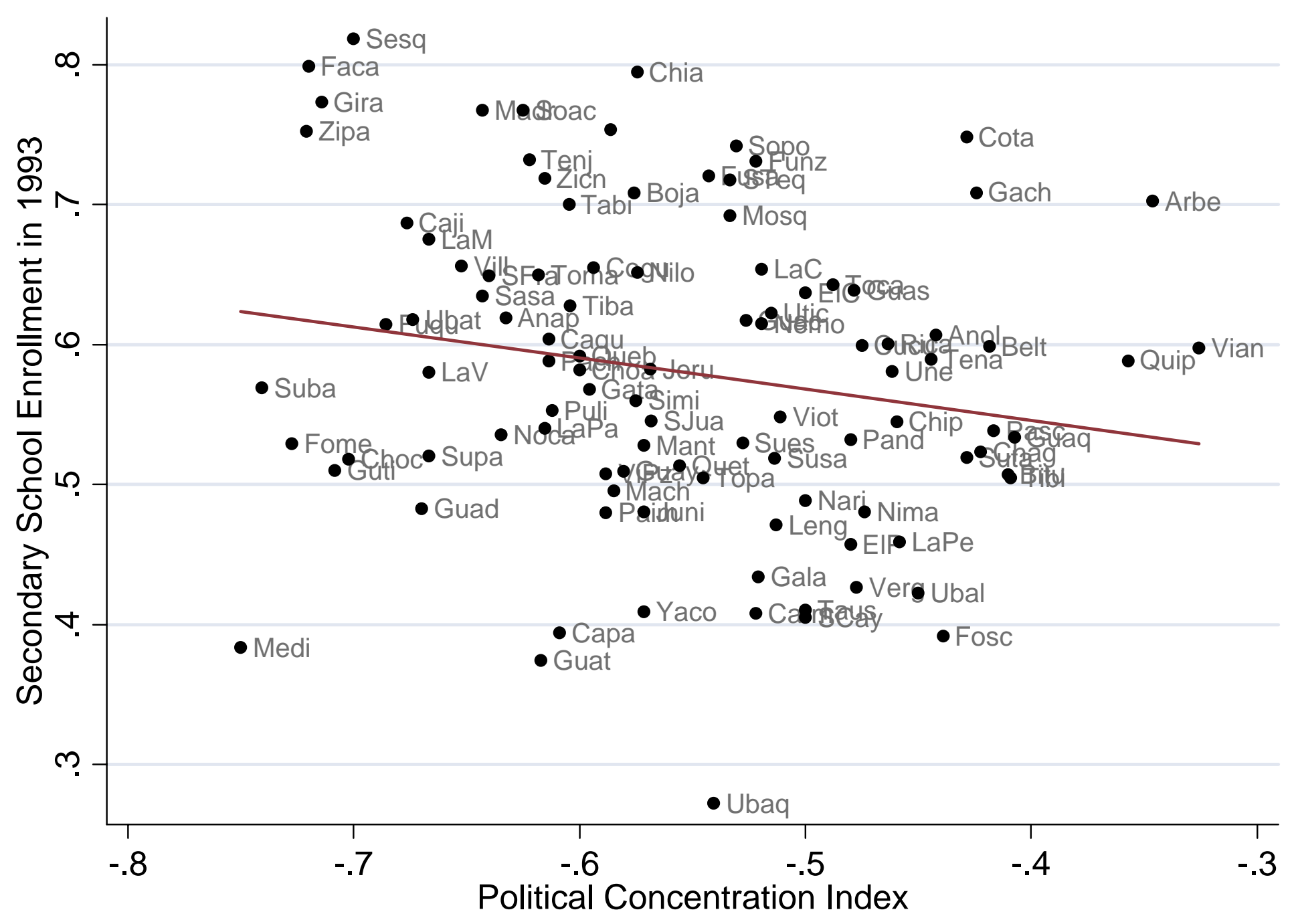

Political Concentration Index defined as the negative of the number of different individuals in power between 1875 and 1895 , over the number of mayor appointments for which data is available. Secondary School Enrollment constructed from the 1993 Census as fraction of kids between 12 and 18 years old attending school. 
Figure 5

\section{Land Gini in Cundinamarca}

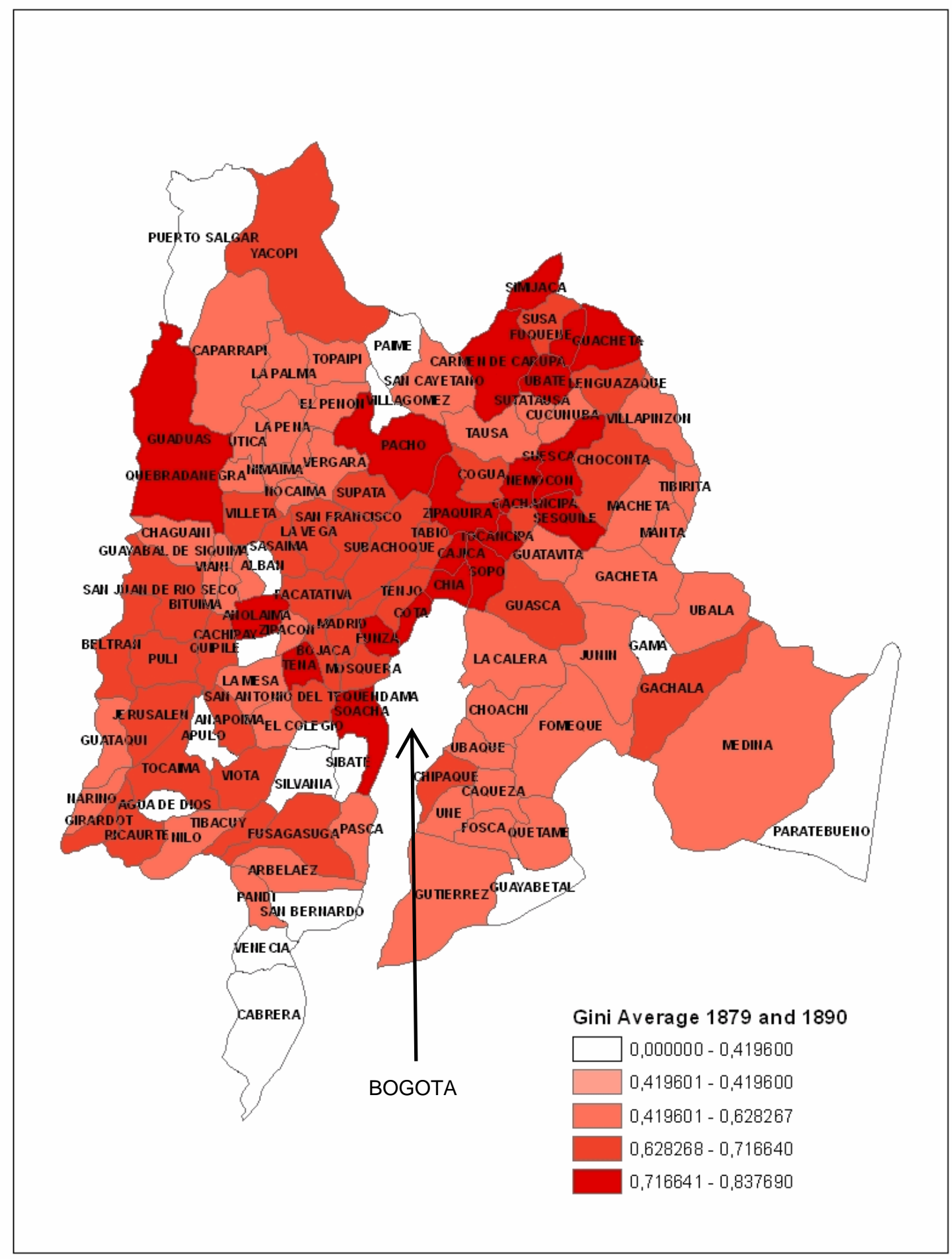

Land gini is the average gini coefficient for 1879 and 1890 constructed from the catastros. 
Figure 6

\section{Political Concentration Index in Cundinamarca}

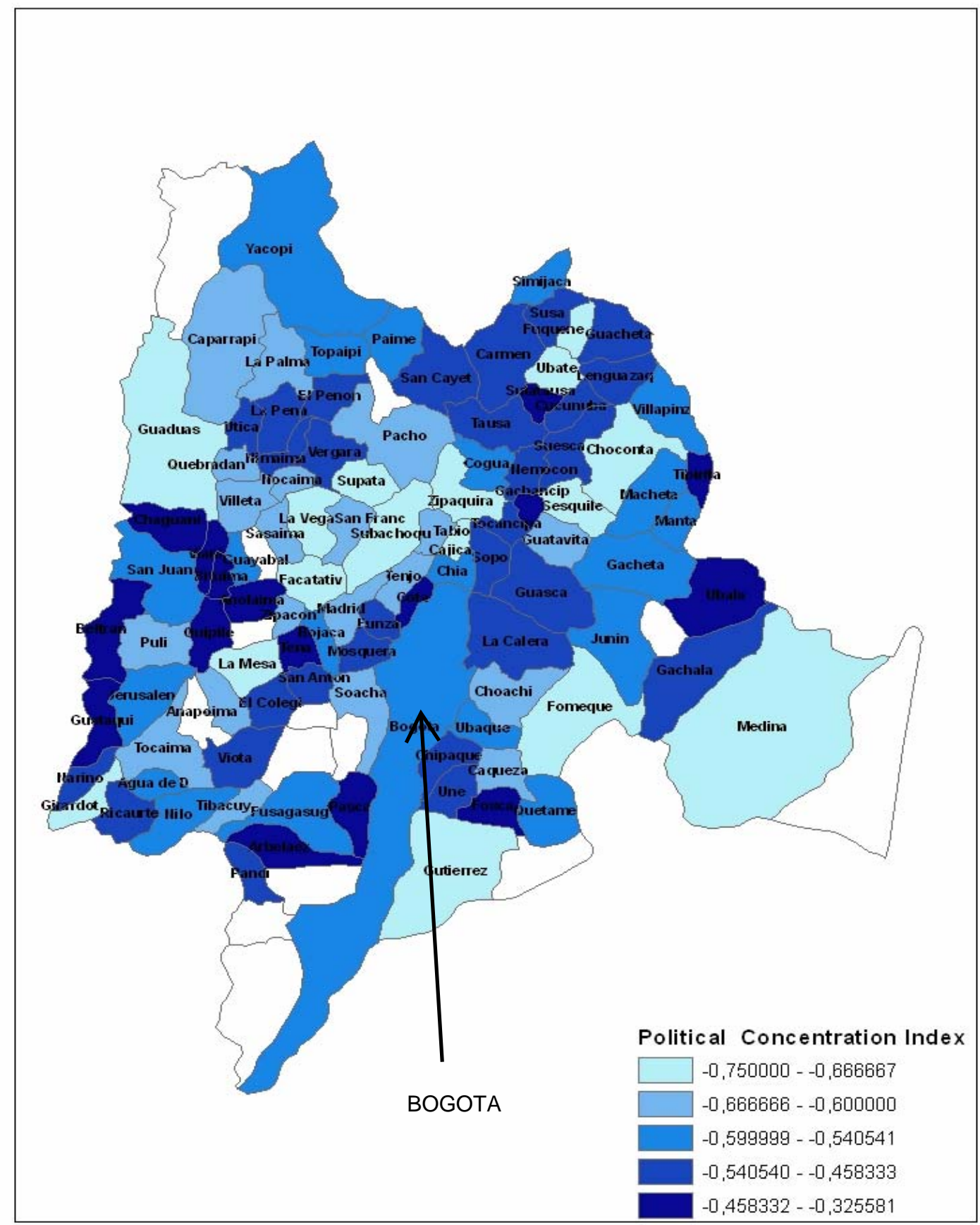

Political Concentration Index defined as the negative of the number of different individuals in power between 1875 and 1895 , over the number of mayor appointments for which data is available. 
Figure 7

Secondary School Enrollment in Cundinamarca

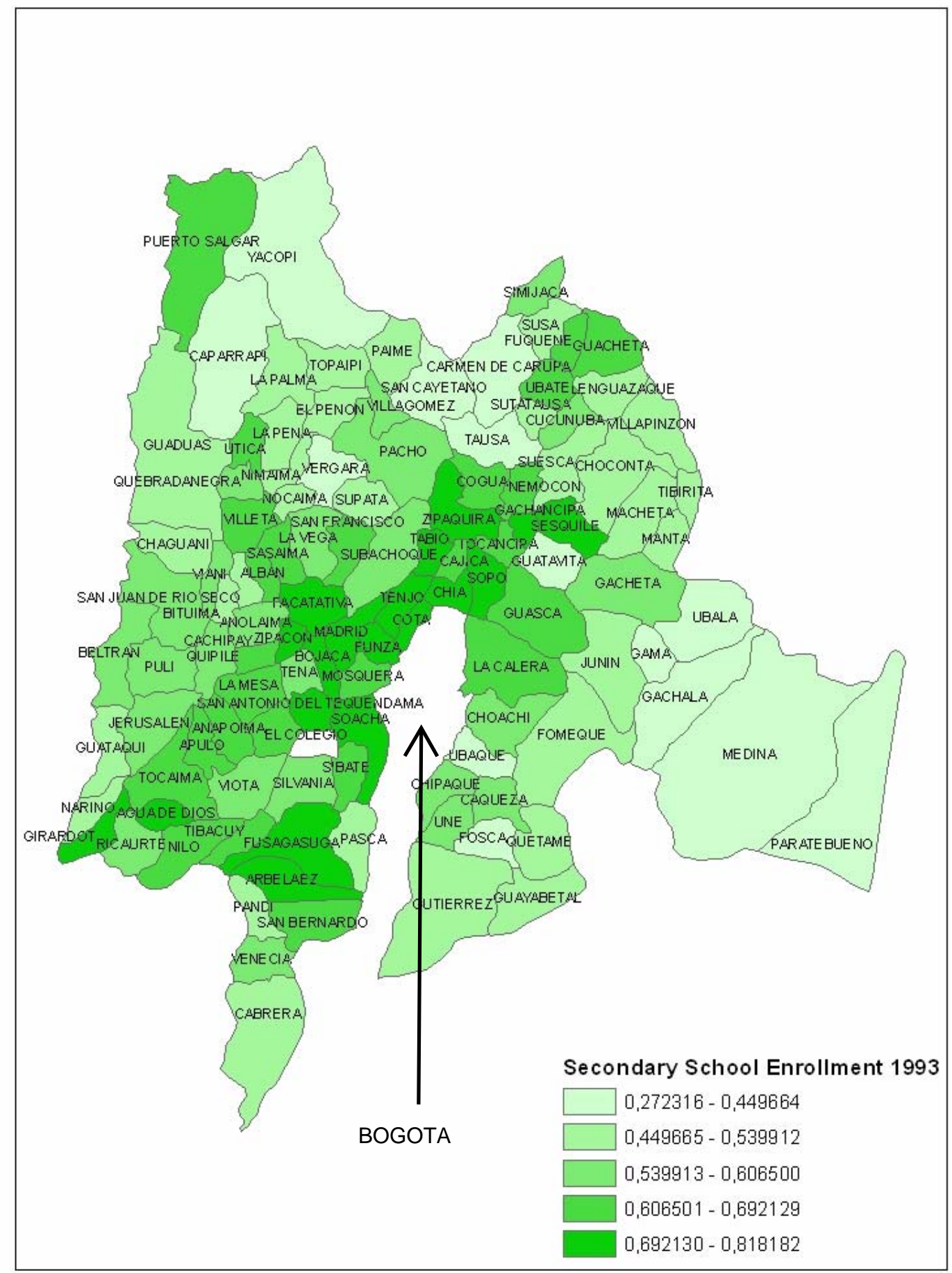

Secondary School Enrollment constructed from the 1993 Census as fraction of kids between 12 and 18 years old attending school. 
Figure 8

Contemporary Land Inequality and Secondary School Enrollment in Colombia

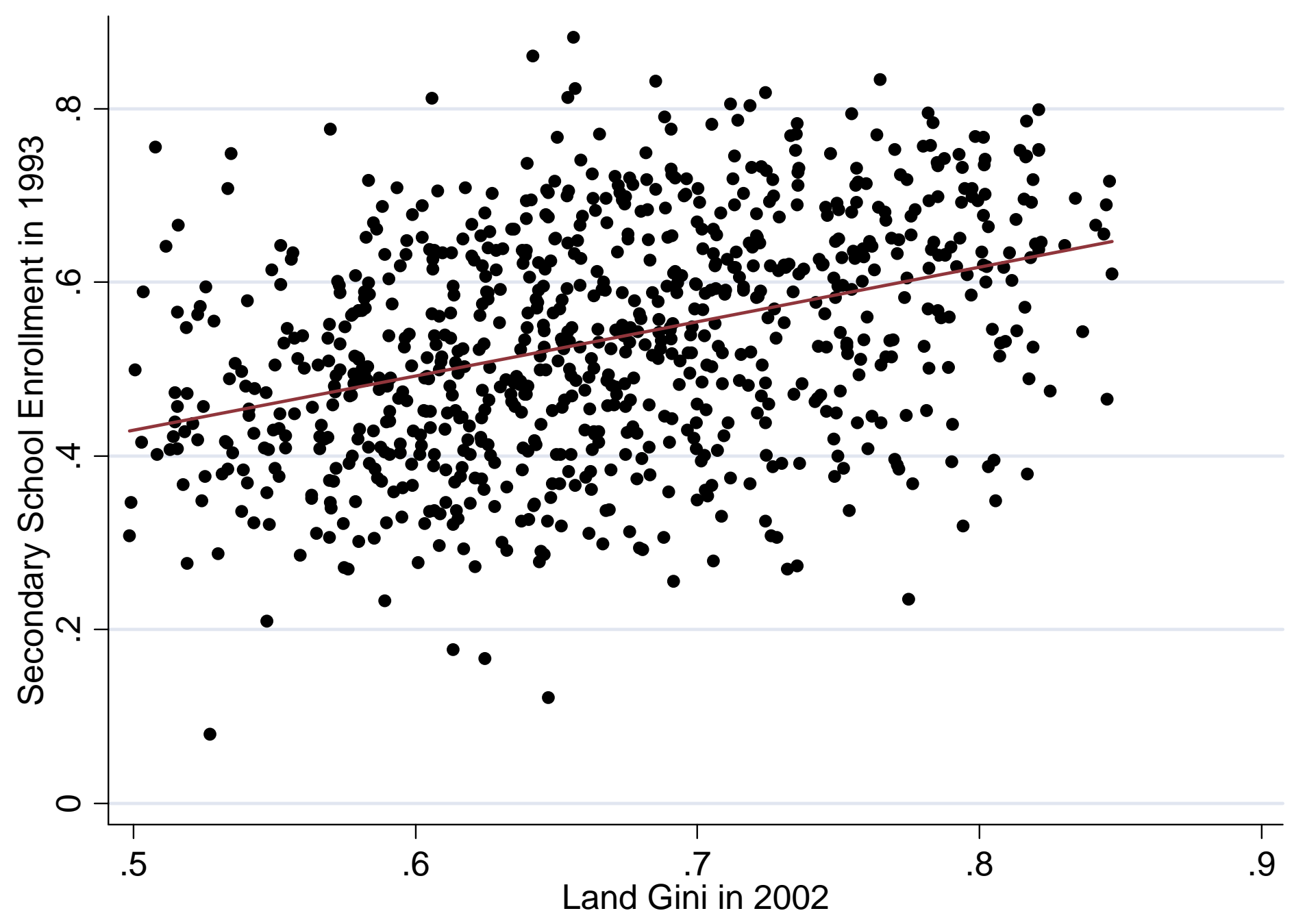


Figure 9

Land Accumulation and Political Power: Quantile Regressions

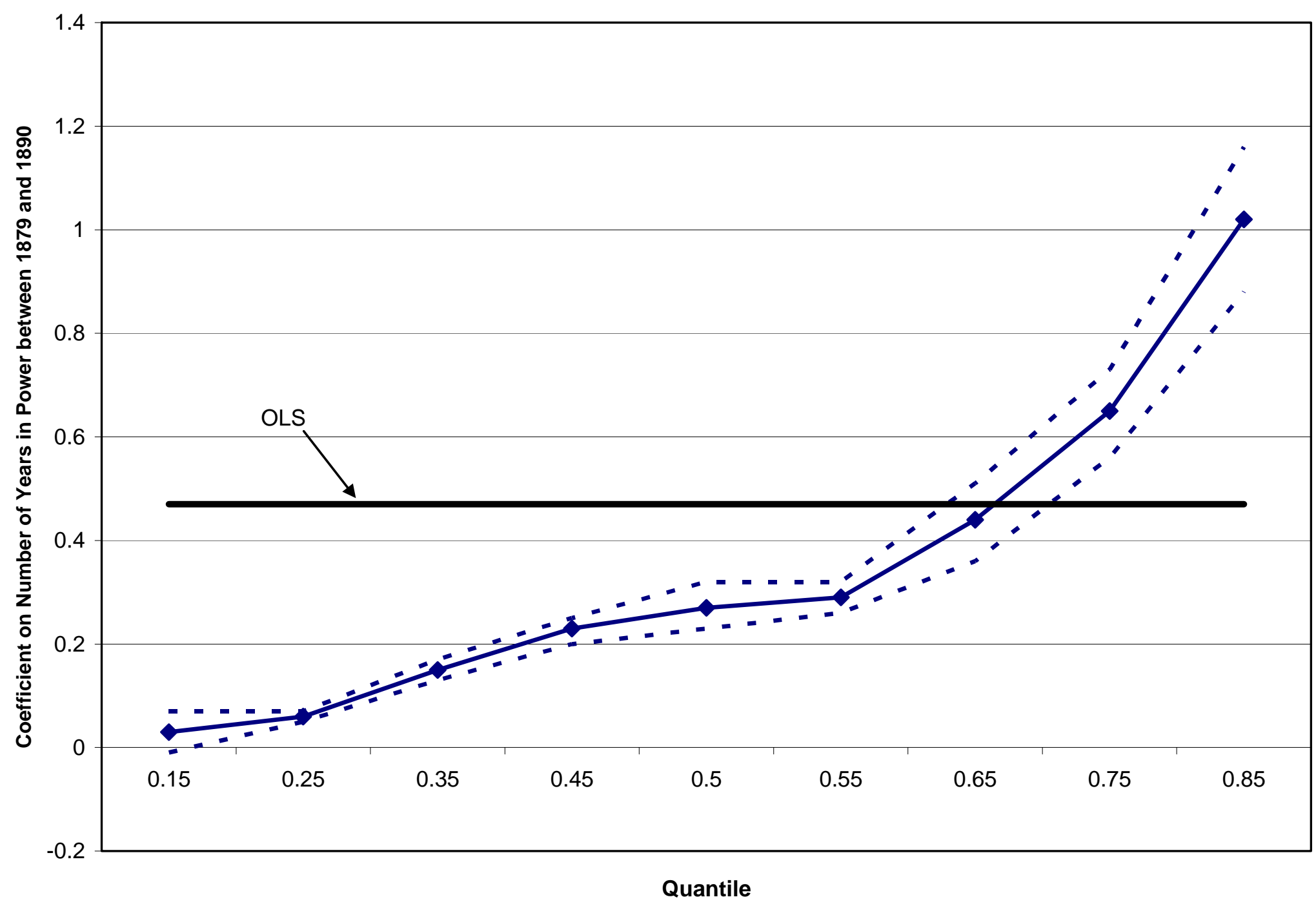

